\title{
Viviane Bersou
}

\section{O Romantismo e a Pequena Forma Pianística:}

\author{
Síntese da composição, \\ a beneficiar o processo didático
}

Dissertação apresentada ao Programa de PósGraduação em Artes, Área de Concentração Musicologia, Linha de Pesquisa Questões Interpretativas, da Escola de Comunicação e Artes da Universidade de São Paulo, como exigência parcial para obtenção do Título de Mestre em Artes, sob a orientação do Prof. Dr. José Eduardo Gandra da Silva Martins.

São Paulo 
Viviane Bersou

O Romantismo e a Pequena Forma Pianística:

Síntese da Composição,

a beneficiar o processo didático

Orientador: Prof. Dr. José Eduardo Gandra da Silva Martins

\section{Banca Examinadora}

Dissertação para a obtenção do Título de Mestre em Artes

Prof.(吕) Dr. $\left(\left(^{a}\right)\right.$

$\overline{\operatorname{Prof} .\left(\frac{a}{)}\right) \operatorname{Dr} .\left(\frac{a}{)}\right)}$

Prof. $(\stackrel{a}{)}) \operatorname{Dr} .\left(\frac{a}{)}\right)$

São Paulo, de

de 2006. 
"Poderei eu falar da minha experiência subjetiva da Música; descrever os estados de emoção estética sem par que o convívio diário e intimo com essa arte maravilhosa me tem proporcionado(...) e como ela é então para mim um bálsamo, e um tônico, e um estimulante, e como ao seu calor espiritual me voltam novamente a calma, a confiança, a energia para prosseguir(...)"...

Fernando Lopes Graça 
Aos meus pais,

pelo ambiente musical que sempre me proporcionaram.

Agradecimentos 
Ao Prof. Dr. José Eduardo Gandra da Silva Martins, pela orientação, esclarecimentos e apoio.

Aos Profs. Dr. Edelton Gloeden e Dr. José Luís Prudente de Aquino, pelo estímulo.

Aos meus alunos, pelos momentos de música. 
Situar a pequena peça romântica para piano no contexto histórico e cultural do século XIX, e dela extrair propostas no campo da didática, é o objetivo desse trabalho. Para isso, procurou-se buscar não só a origem, mas justificar a preferência da pequena forma por parte dos compositores, em detrimento de formas maiores, já consagradas e aceitas universalmente.

Fatores como o aperfeiçoamento do piano, estrutura, características e titulação das peças são abordados, assim como o movimento nacionalista, que tão bem delas se utilizou como veículo de expressão.

A obra Macchiette op.2, coletânea de Henrique Oswald, serviu de exemplo vivo para ilustrar e justificar o que foi proposto: peças descritivas, intimistas, danças, revelam não só as tendências da época, mas as características, o estilo do compositor, que, através delas e de maneira particular, original, subjetiva, expressa suas emoções e se deixa conhecer.

\section{Abstract}


The objective of this paper is to place this small romantic piano piece in the historical and cultural setting of the XIX century and extract from it some new ideas for teaching.

For this reason, we tried to get at its very origins and justify the preference for the small form favored by the composers rather than larger, already consecrated and universally accepted forms. Factors such as perfecting the piano as well as structure, characteristics and studying the titles of the pieces were looked at, just as the nationalist movement that at the time used them for expression.

Macchiette op.2, compiled by Henrique Oswald, is a lively example to illustrate and justify the purpose: descriptive, intimistic pieces, dances, revealing not only trends of their time, but the features and style of the composer who, in a very particular, original and subjective way, used them to express his feelings and make himself known.

\section{SUMÁRIO}




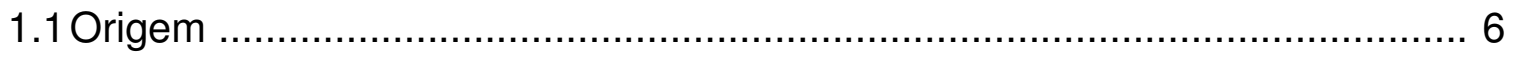

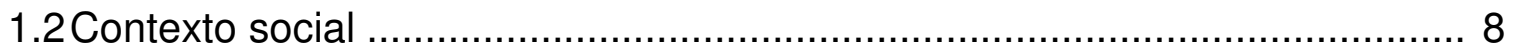

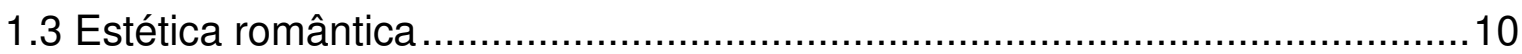

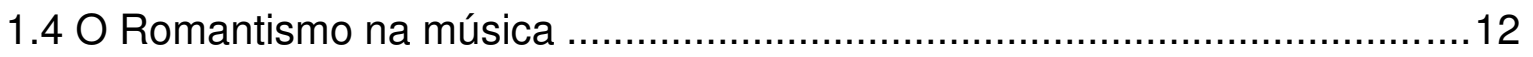

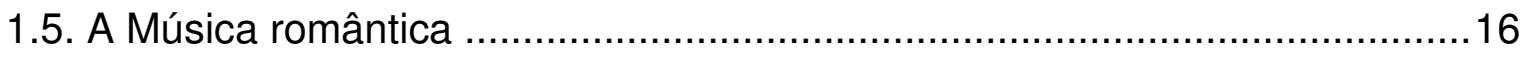

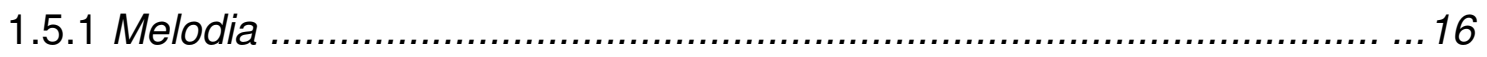

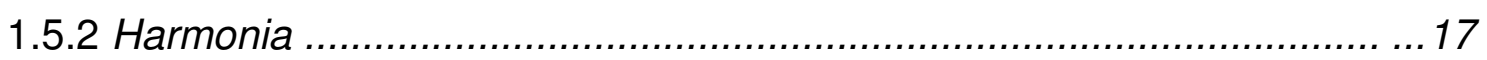

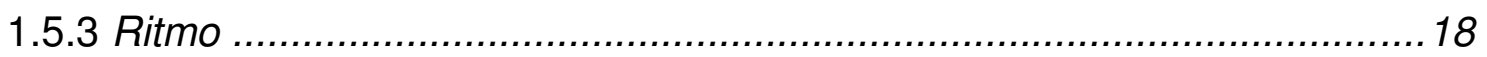

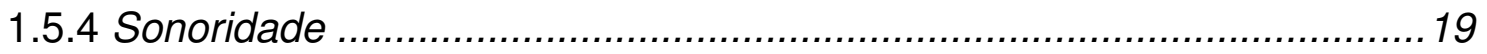

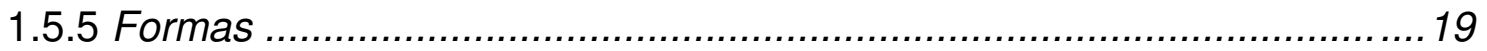

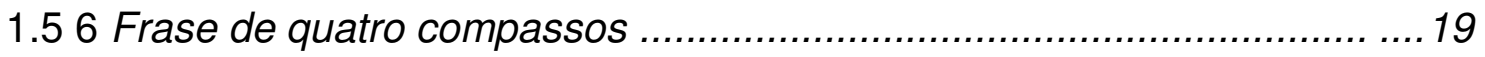

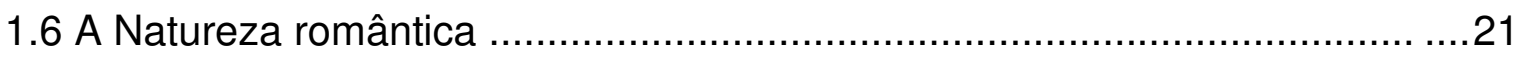

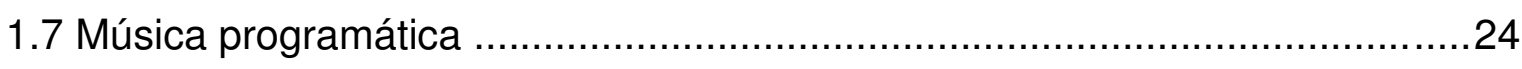

1.8 Da suíte barroca à pequena forma romântica ............................................25

Capítulo 2 O PIANO E A PEQUENA FORMA MUSICAL ..................27

2.1 O piano: importância e conseqüências da descoberta de suas plenas

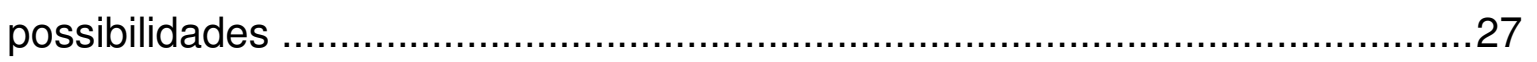

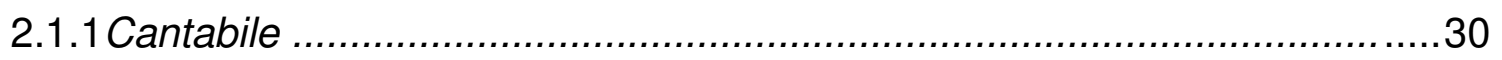

2.1.2 Virtuosismo

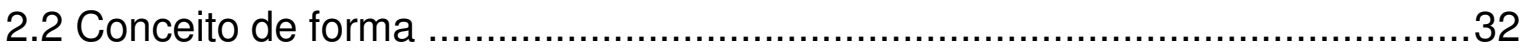

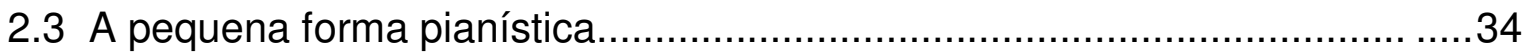

2.4 Nacionalismo: a pequena forma pianística como veículo de expressão.........39

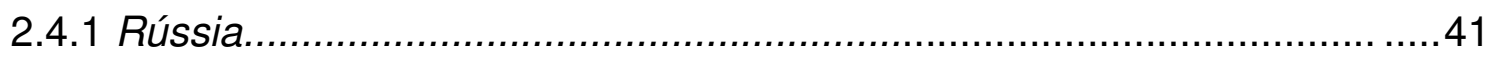

2.4.2 Noruega

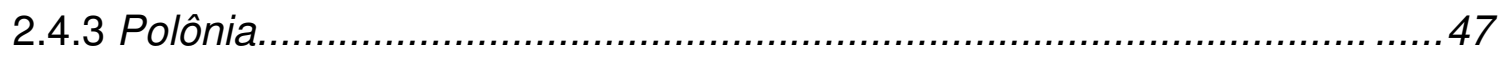

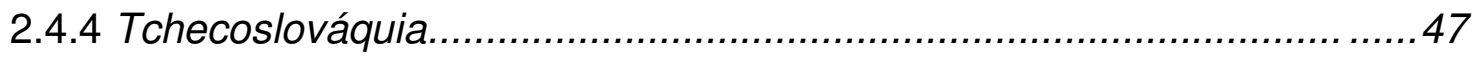

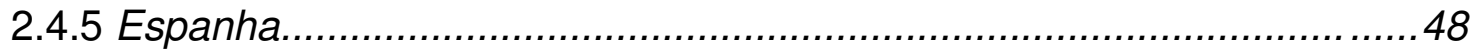

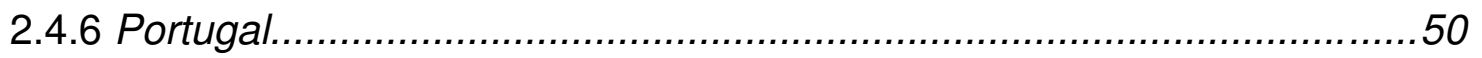

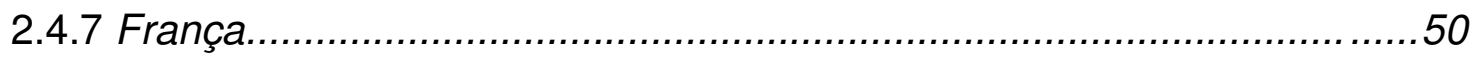

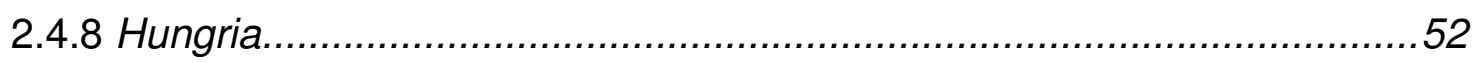

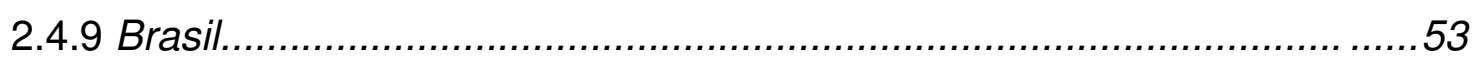


Capítulo 3 MACCHIETTE OP. 2 DE HENRIQUE OSWALD: TÍPICA COLETÂNEA ROMÂNTICA

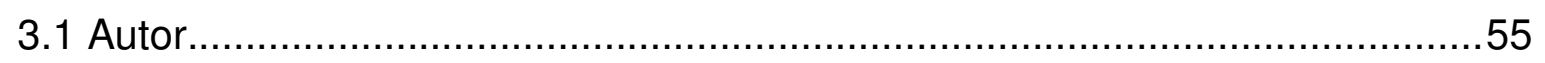

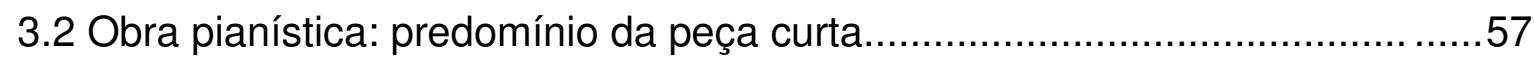

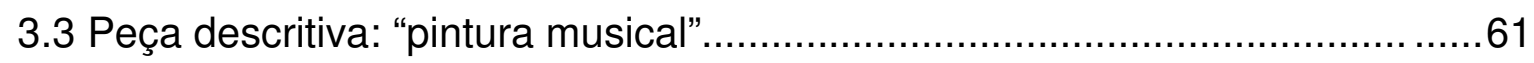

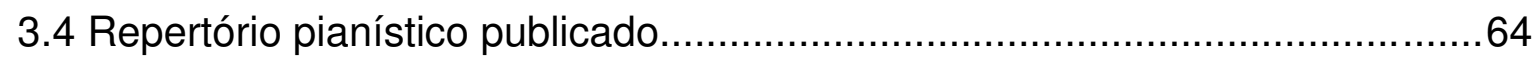

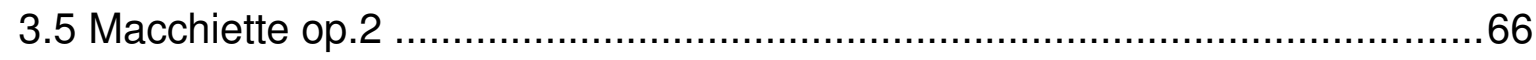

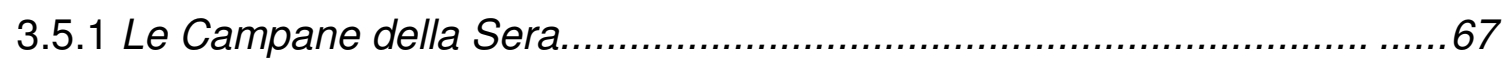

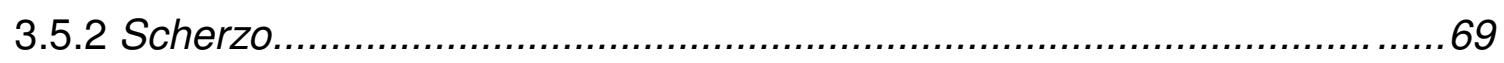

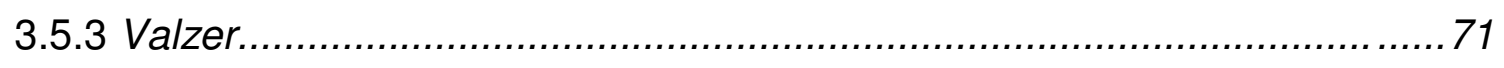

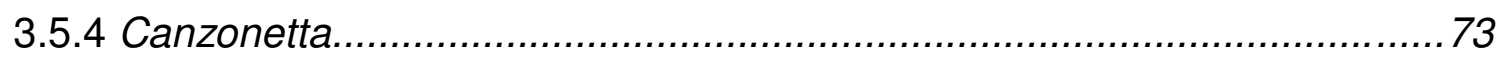

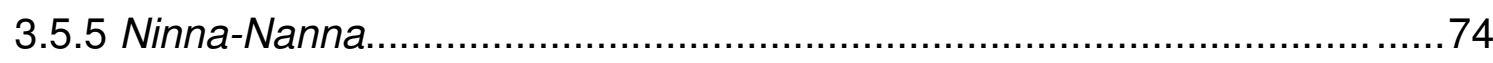

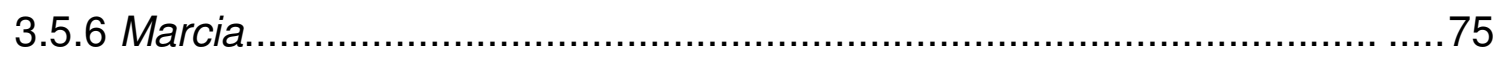

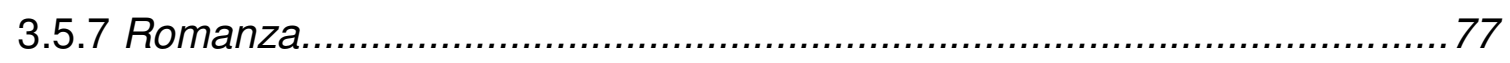

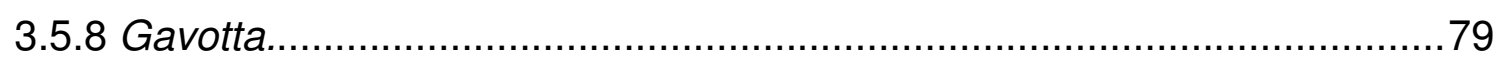

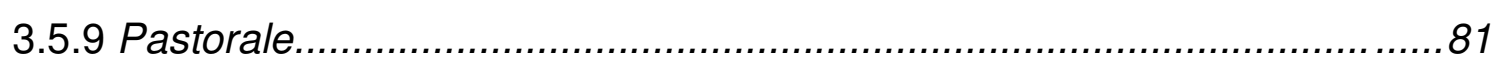

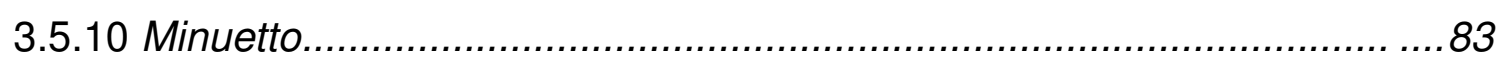

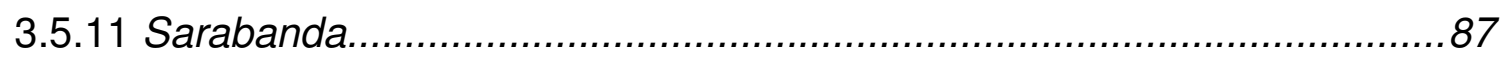

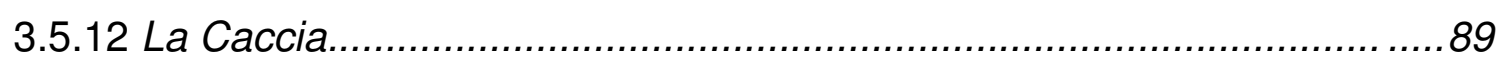

Capítulo 4 PROCESSO DIDÁtICO ATRAVÉS DA PEQUENA FORMA.............................................................................. 93

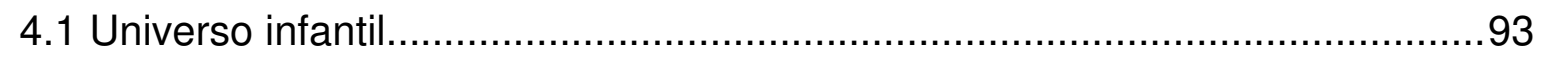

4.2 Pequena forma: síntese do processo criativo a beneficiar a

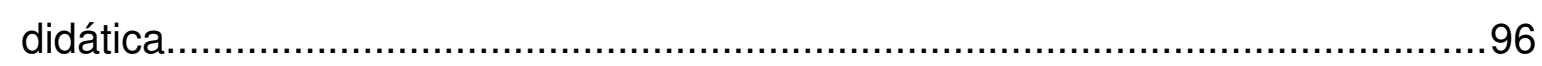

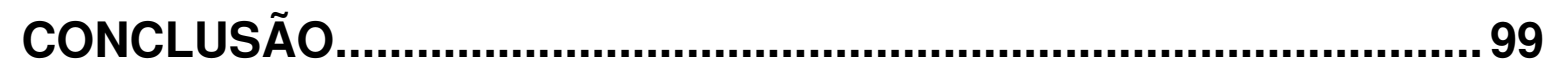

BIBLIOGRAFIA............................................................................101

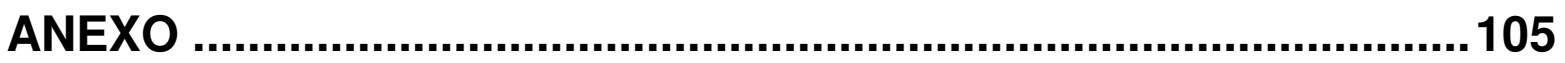




\section{Introdução}

Gênero tipicamente romântico, a pequena forma para piano teve grande importância pelas inovações estéticas apresentadas e por satisfazer as necessidades de uma sociedade contagiada pela emoção, um dos paradigmas do Romantismo, a influenciar amplamente o repertório pianístico até o início do século $\mathrm{XX}$.

Meio propício para a criatividade melódica e investigações harmônicas, essa forma transformou-se em verdadeiro laboratório musical, refletindo a expressão dos anseios mais íntimos do compositor e representando a síntese dos procedimentos por ele utilizados.

Na didática pianística, o estudo dessas peças é um importante fator para o conhecimento de questões referentes à técnica e interpretação, proporcionando àqueles que têm conhecimento desse repertório, relevantes informações sobre as características do autor, do seu estilo e, conseqüentemente, de parcela considerável do período romântico.

A escolha do tema justifica-se pelo contato direto com essas obras durante anos de estudo e ensino, e pela conseqüente observação de tudo o que possa ser extraído desse rico material, para a consecução de uma interpretação que atenda aos atributos expressivos.

Para melhor entender a forte presença e desenvolvimento da pequena forma pianística, inicialmente foi feito um levantamento do contexto histórico e cultural do século XIX, por ter sido esse período responsável pela grande influência exercida nas artes em geral. 
Foi importante buscar respostas sobre o porquê da preferência pela pequena forma entre os compositores românticos, para abordar, numa etapa posterior, suas características, estrutura, titulação, divulgação, assim como a importância da evolução apresentada pelo piano, instrumento que melhor traduziu o conteúdo expressivo dessas obras.

Também foi feito um estudo sobre a peça descritiva, comparando-a com a do período barroco e sobre a nova visão que o artista romântico passou a ter a respeito da natureza.

A importância da pequena forma como veículo de expressão das tendências nacionalistas e a conseqüente diversidade de repertório também foram comentadas, notadamente em países como: Rússia, Noruega, Polônia, Tchecoslováquia, Espanha, França, Portugal, Hungria, Brasil.

Com um levantamento preliminar das características composicionais de Henrique Oswald, a obra Macchiette op.2 foi estudada no terceiro capítulo, por representar a típica coletânea romântica, constituída de diferentes tipos de peças: música descritiva (Le Campane Della Sera, La Caccia); peça característica (Scherzo); danças (Valzer, Gavotta, Minueto, Sarabanda); obras de caráter intimista (Canzonetta, Romanza, Ninna-Nanna) e bucólico ( Pastorale).

Foi particularmente importante o contato direto com a obra Macchiette, a fim de interpretá-la, quer para superar as dificuldades técnicas apresentadas, quer para melhor perceber o estilo e as reais intenções do compositor.

Os títulos descritivos e as melodias da coletânea possibilitaram a evocação de temas semelhantes abordados por outros compositores da época e sua posterior comparação. Poder-se-ia considerar que há em Macchiette, um multum in mínimo referente aos procedimentos técnico-pianísticos de Henrique Oswald. 
Pequenas formas com a temática exclusivamente do universo lúdico foram comentadas em composições de Schumann, Mendelssohn, Tchaikovsky, César Franck e Debussy, no último capítulo.

Também se falou sobre o que é possível apreender, do ponto de vista composicional e didático, da análise e interpretação da pequena forma romântica.

$\mathrm{Na}$ bibliografia consultada, a pequena forma encontra-se presente no repertório dos compositores ao longo do século XIX. A fim de uma delimitação histórica, iniciou-se com Schubert prosseguindo-se com Schumann, Chopin, Mendelssohn, Liszt, estendendo-se essa panorâmica até o início do século XX.

O tema da dissertação foi pesquisado em capítulos referentes ao Romantismo na música, literatura, pintura, assim como em compêndios sobre forma.

De grande valia foram as obras do Prof. José Eduardo Martins sobre Henrique Oswald, onde são encontradas informações sobre o destino e titulação da pequena peça, além de dados sobre a elaboração dos programas dos recitais. Também Adolfo Salazar, Charles Rosen, Jean Chantavoine e Jean Gaudefroy-Demonbynes são nomes significativos, por abordarem, em suas obras,a música romântica sob vários ângulos.

No final deste trabalho, foi inserido um anexo, contendo as partituras das doze peças da coletânea Macchiette op. 2 de Henrique Oswald. 


\section{Capítulo 1: O ROMANTISMO}

\subsection{Origem}

A palavra "Romântico" surge na crítica literária e de arte durante o século XVIII. É de origem inglesa (romantic) e deriva do substantivo "roumant", de origem francesa, que designava os romances medievais de aventura. Inicialmente, referiase a tudo o que evocava a atmosfera fantástica, misteriosa, desses romances - a cavalaria e, em geral, a Idade Média, em contraste com a tradição clássica, até então preponderante.

No final do século XVIII, o termo abrangia uma série de novas tendências encontradas em vários aspectos da vida: arte, filosofia, política.

Embora o norte da Europa tenha sido mais suscetível que o sul aos efeitos do espírito romântico, nenhum país permaneceu imune a ele. Entre as nações, ocorreu primeiro na Inglaterra , Alemanha e França. Entre as artes, inicialmente na poesia, depois na pintura e na música.

$\mathrm{Na}$ literatura inglesa, manifestou-se precocemente no século XVIII. A Alemanha, devido à ausência de uma burguesia mercantil e industrial significativa, tornou-se o centro originário do Romantismo na sua versão mística, conservadora.

Os ideais românticos de liberdade e individualismo encontraram importante forma de expressão no racionalismo francês.

Segundo Longyear ${ }^{1}$, é possível identificar as seguintes fases do período Romântico:

- Romantismo precoce: por volta de 1800;

${ }^{1}$ LONGYEAR, Rey Morgan. Nineteeth-century romanticism in music. New Jersey, Prentice-Hall, 1988, p.22. 
- pleno Romantismo: entre 1815 e 1840;

- Romantismo tardio: entre 1850 e 1890;

- exacerbação do Romantismo ou pós-Romantismo: surgiu com a expressão fin de siècle, entre 1885 e 1914, ocorrendo tanto na música quanto nas artes visuais e na literatura.

É impossível encontrar uma definição de Romantismo que seja válida para todas as artes e países, capaz de rotular, com precisão, as obras do período. Para os compositores da época, definir o Romantismo musical é tão vago e contraditório como para seus correspondentes literários, segundo as análises de obras de críticos do século XIX. A declaração de Victor Hugo sobre o Romantismo, como sendo "uma vaga e indefinível fantasia", reforça a dificuldade de uma definição concreta ${ }^{3}$.

Portanto, observar temas tais como individualismo, nacionalismo, interpenetração das artes, que permeiam a estética romântica, é a forma mais conveniente para o entendimento do período.

\subsection{Contexto Social}

A história do Romantismo está associada às revoluções e contra-revoluções européias e suas conseqüências. São seus marcos:

\footnotetext{
${ }^{2}$ Apud LONGYEAR, Rey Morgan., op.cit., p.8.

${ }^{3}$ José Eduardo Martins entende o Romantismo "como um movimento pleno de vertentes, mas uno. Partindo do final do século XVIII e considerando-se a morte de Rachmaninov em 1943, tem-se mais de um século e meio em que jamais houvesse descontinuidade do espírito, do estilo, do pensamento romântico. Flutuações, sim, existiram, mas não descontinuidade como no caso, por exemplo, do período Barroco, que teve começo, meio e fim". Depoimento verbal à autora.
} 
- Revolução Industrial - importante na Inglaterra por volta de 1800, espalhouse por toda a Europa e mesmo Japão e Estados Unidos, no final do século XIX;

- Revolução Francesa ( 1789 );

- a queda de Napoleão ( Waterloo, 1815 ).

Para Karl Mannheim ${ }^{4}$, as atitudes saudosistas da nobreza, ou reivindicatórias da burguesia que ainda não subiu, presentes em todo o movimento romântico, decorrem dos sentimentos de insatisfação perante as novas estruturas.

Definem-se as classes: a nobreza, há pouco no poder; a grande e a pequena burguesia; o homem do campo; o operariado crescente. Ao lado de um proletariado cada vez mais numeroso, surge uma reduzida mas poderosa burguesia industrial e financeira.

A produção passa a ser a base da economia. Segundo Adolfo Salazar ${ }^{5}$, o homem, na nova sociedade, não mais depende exclusivamente de seu nascimento ou herança. Utiliza-se agora de valores próprios, específicos, tais como o intelectual, o científico e o industrial, que resultam respectivamente em obras de arte, obras de pensamento e objetos. Portanto, produção sempre.

Estatísticas da época comprovam um notável crescimento populacional no século XIX (por volta de 200 milhões, na Europa, em 1800, a 505 milhões, em 1914) e também urbano. Estimava-se que de sete pessoas nascidas na Europa rural, cinco mudavam-se para as cidades.

Em meados do século XIX, rápidas transformações ocorrem nas condições de vida: surgem as estradas de ferro; túneis e canais são abertos; generaliza-se a navegação. Com a invenção do concreto reforçado e do elevador, as cidades passam a crescer verticalmente.

\footnotetext{
${ }^{4}$ Apud BOSI, Alfredo. História Concisa da Literatura Brasileira. São Paulo, Cultrix, 1972, p.100.

${ }^{5}$ SALAZAR, Adolfo. Conceptos fundamentales en la história de la musica. Madrid, Alianza Editorial, 1988, p. 142.
} 
Uma nova revolução industrial ocorreu, no final do século, não mais baseada no ferro, carvão ou máquina a vapor, como antes, mas no aço, eletricidade, produtos químicos. Aperfeiçoamentos tecnológicos reforçaram-se mutuamente, resultando em progressos na agricultura, transporte, comunicações.

Mais e mais pessoas tiveram acesso ao lazer, educação e mesmo começaram a tomar parte em eventos culturais e artísticos. Instituições educacionais, hotéis, hospitais, bibliotecas, salas de concerto, ruas pavimentadas, iluminadas e outras comodidades urbanas passaram a medir os índices de qualidade de vida.

Embora esse crescimento resultasse em suporte econômico para as artes e proporcionasse inúmeros melhoramentos, o exagero do materialismo e as condições desumanas de trabalho nas fábricas foram a causa da revolta de muitos que sentiam a necessidade de mudanças sociais.

\subsection{Estética romântica}

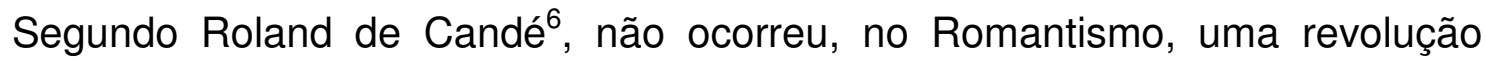
estética nítida, uma ruptura com o passado. Na ausência de uma doutrina coerente, a estética romântica tornou-se mais um demonstrativo de uma maneira de ser, um conjunto de novas atitudes, do que uma série de características.

Entre essas atitudes encontram-se:

\footnotetext{
${ }^{6}$ CANDÉ, Roland de. História Universal da Música. São Paulo, Martins Fontes, 2001, v.2, p. 11.
} 
- exaltação da originalidade, em oposição à teoria clássica da imitação;

- importância conferida à ficção, ao fantástico;

- confraternização com a natureza;

- valorização dos sentimentos;

- predomínio da intuição sobre a razão;

- individualismo;

- elevação do artista.

Idéias como originalidade, emoção, expressividade, sentimento, já ocorriam em épocas anteriores, porém, tornaram-se agora inconfundíveis pelo predomínio e intensidade que chegaram a assumir.

O que prevalece agora não é mais o valor objetivo da obra, mas o ato da criação - espontâneo, autêntico, original - a revelar a subjetividade de seu criador. Portanto, o elemento primordial de avaliação deixa de ser o estético.

O sentimento de inadequação social por parte do artista romântico origina-se do conflito entre as limitações do real e a infinitude do ideal, e resultam em insatisfação e nostalgia. Daí a evasão da realidade no tempo e no espaço, "recriando" a Idade Média ou "descrevendo" o Oriente exótico, onde acreditam encontrar uma sociedade unificada e uma cultura integrada. A grande síntese levaria à fusão mística com o Universo em sua infinitude.

O artista romântico também assume posturas regressivas em relação ao "eu" através do sonho, devaneio, imaginação, solidão.

Velhas riquezas vêm à tona e revivem com o Romantismo: lendas, mitos, usos, costumes, antigas melodias. Sendo a época romântica um período de exasperação da sensibilidade, teve o sentimento do amor expresso com maior intensidade e freqüência. 
O Romantismo foi o primeiro movimento estético musical a tomar consciência de suas intenções, o que resultou na designação conferida.

\subsection{O Romantismo na música}

A música romântica surgiu evidenciando a forte expressão e a comunicação direta. Seria possível considerar que o movimento romântico musical expressa o entusiasmo, fantasias e revoltas desse período. Há a presença igualmente do caráter indefinido, ideal, sugestivo. 
Tendo uma forte expansão, alcançou lugares por ela antes pouco freqüentados e encontrou um público novo, cada vez mais numeroso, mas de certa forma anônimo.

Contribuíram para a expansão da vida musical os seguintes fatores:

- proximidade dos povos facilitada pelo desenvolvimento dos meios de transporte;

- difusão das obras musicais, decorrente do aumento do número de concertos;

- progressos consideráveis no comércio e edição de partituras, com o objetivo de satisfazer a crescente demanda;

- desenvolvimento da musicologia, suscitando o interesse pela música de um passado recente.

Ao lado dos concertos privados e das execuções amadorísticas, a democratização da vida musical tornou necessária a abertura de grandes salas de concerto. Organizações especializadas, empresários ou grupos de músicos substituíram, aos poucos, o papel de patronos e mecenas nobres, encarregando-se da organização dos concertos públicos.

Modificando naturalmente o estatuto social do músico, a Revolução Francesa altera as condições da comunicação artística. Isento de suas obrigações para com a Igreja e a Corte, o músico compõe o que Ihe agrada e apresenta-se onde deseja.

Embora com as condições de trabalho alteradas e seus direitos elementares reconhecidos, o músico, por muito tempo, necessitará encontrar um emprego fixo, a fim de garantir sua subsistência.

Cercados pela elite, mas não integrados a ela, preocupados com a incerteza da reação de um público desconhecido, os artistas tornam-se egocêntricos e mantêm-se cada vez mais afastados da sociedade. 
Segundo Adolfo Salazar ${ }^{7}$, o músico romântico fará a transposição musical de suas emoções. A grandeza de sua obra depende do êxito em relacionar a identidade de sua paixão, com a paixão que move o Universo.

A literatura serviu de referência para o Romantismo musical, e obras de Shakespeare, Byron, Goethe e Hoffmann inspiraram muitos compositores.

Diferentemente de épocas anteriores, onde a "substância" é o elemento a ser trabalhado (a matéria pictórica, na pintura, e a sonora, na música), a necessidade expressiva terá prioridade no Romantismo e a forma será um processo de acomodação. Já em 1739, Mattheson ${ }^{8}$ dizia: "A música brota diretamente da emoção, da qual extrai sua substância".

Portanto, expressar a própria alma será o objetivo primeiro, que resultará na importância conferida ao pessoal, individual.

Essa concepção romântica da música como expressão das emoções de um "eu" profundo, não traduzível através das palavras, é adequada à índole alemã, que não a vê como uma distração. Linguagem do subconsciente, arte do infinito, ocupou a música alemã o primeiro lugar na hierarquia das artes, reação contra a influência do racionalismo francês.

Liszt $^{9}$ também considera a música linguagem universal, que comunica 0 sentimento humano através da melodia, igualmente compreensível a todos os seres.

Algo semelhante expressa o poeta espanhol Nicolás Zuricalday ${ }^{10}$, no poema "A lição de Música":

"O aroma, a cor, a poesia,

\footnotetext{
${ }^{7}$ SALAZAR, Adolfo. Forma y Expression en la Musica. México, El Colegio de Mexico, 1941, p. 69-70.

8 Apud. CHANTAVOINE, Jean \& GAUDEFROY-DEMONBYNES, Jean. El Romanticismo en La Musica Europea. México, Union Tipografia Editorial Hispano Americana, 1958, p.29.

${ }^{9}$ Ibidem, p.32.

${ }^{10}$ Ibidem, p.32
} 
tudo é música, Inês, tudo harmonia,

e mesmo o azul do firmamento

é melódico acento,(...)

A música é a alma das coisas!"

Da contemplação da natureza resultou o panteísmo místico. Dela, o artista retira inspiração para sua arte e, indiretamente, de Deus, criador da natureza. Portanto, a proximidade com Deus, no século romântico, poderia ser conseguida em comunhão com a natureza.

Artistas românticos, influenciados pelas teorias de críticos alemães, como Herder, Schiller e os irmãos Schlegel, mantinham a esperança de renovação através da poesia e da música populares, nas quais acreditavam não poder haver nada de fictício e artificial. Porém, somente no final de século XIX, o folclore musical será aproveitado de forma consistente.

Segundo Adolfo Salazar"11, é possível considerar a música "romântica" a voz de uma sociedade "romântica", que se estende por toda a Europa, unindo os povos, pelo menos até o período mais exaltado, antes de as diferenças nacionais se acentuarem.

Mesmo ocorrendo influência entre os compositores, é tão importante identificar o vocabulário geral quanto as características pessoais da linguagem romântica.

${ }^{11}$ SALAZAR, Adolfo. La Musica en la Sociedad Europea. México, El Colegio de Mexico, 1946, v.3, p.52. 


\subsection{A Música romântica}

O racionalismo excessivo fez com que, já no século XVIII, surgisse entre os teóricos, uma "inquietação harmônica". E nas obras dos compositores do século XIX, uma incessante transformação ocorreu na escrita pianística, na harmonia, na forma das peças, a fim de expressar um "algo novo", que agora pulsa e vibra nas obras. É a busca da liberdade de uma "força explosiva", aprisionada por tanto tempo, como escreve Adolfo Salazar. ${ }^{12}$

${ }^{12}$ SALAZAR, Adolfo. Conceptos fundamentales en la historia de la musica. Madrid, Alianza Editorial, 1988, p.35. 
1.5.1 Melodia: Assim como na poesia, ocorreu na música, a distensão do ritmo em função da melodia, por ser esta um veículo mais adequado às expressões dos sentimentos. O Romantismo substituiu, gradativamente, a articulação da música clássica por uma linha menos definida. A melodia tornou-se flexível, aberta, livre, afetiva, favorecendo a expressividade musical e, na poesia, o lirismo.

Para Franco Abbiatti, ${ }^{13}$ a música romântica identifica-se com uma melodia sem fim, que flutua, vaga, ondula no espaço e se afirma como arte.

A textura da "melodia com acompanhamento" ainda prevalece, mas as modulações, agora freqüentes, enfatizam o subjetivismo, característica da melodia romântica.

As qualidades de "cantar" dos instrumentos são exploradas nas características vocais da melodia. Segundo E.T.A. Hoffmann ${ }^{14}$, o esforço inútil de uma série de sons para converter-se em música define uma melodia não cantabile.

1.5.2 Harmonia: Uma das grandes preocupações dos compositores românticos, a harmonia foi o principal meio utilizado para expressar a individualidade e originalidade. Um grande número de tratados e livros sobre harmonia surgiu entre 1800 e 1914.

Embora a harmonia tonal tenha permanecido como princípio no século XIX, a utilização cada vez mais livre das dissonâncias não resolvidas e cromatismos conduziu os compositores até as fronteiras do sistema tonal.

Priorizando as sensações, a harmonia empregada no Romantismo, com suas constantes modulações, favoreceu o aspecto emocional. Schumann assinalou como novidade da harmonia, o poder de expressar sentimentos muito mais diversos do que os produzidos pela harmonia clássica.

\footnotetext{
${ }^{13}$ ABBIATTI, Franco. Historia de La Musica. Ottocento( Siglo XIX ). Mexico, Union Tipografia Editorial Hispano Americana, s.d., v.4, p. 21.

${ }^{14}$ Apud. ABBIATTI, Franco., op.cit., p. 20.
} 
Sendo a subjetividade beneficiada pelo cromatismo, a dissonância favoreceu a linguagem, a expressão do herói romântico em sua constante insatisfação.

O Dr. Ernst Kurth ${ }^{15}$ define a harmonia pelo aspecto dinâmico. Para ele, a multiplicidade das dissonâncias e alterações da harmonia romântica requerem uma resolução melódica, trazendo mobilidade ao discurso musical, refletindo a inquietude, a instabilidade do homem romântico.

Segundo Jean Chantavoine ${ }^{16}$, as constantes alterações harmônicas resultam numa espécie de "irisação", de um colorido mais amplo da música. Esse aspecto cinestésico também é mencionado por E.T.A. Hoffmann em sua Kreisleriana. Para ele, é possível falar em "cor" e "brilho", para os sons. Assim como um físico assegura que a "audição é uma visão interna", para o músico, "a visão é uma audição externa".

Também os poetas Baudelaire, Verlaine, músicos como Scriabin e mesmo o historiador Oswaldo Spengler perceberam a música como uma "audição colorida", parte de uma grande cinestesia, na qual "palavras são sons e sons são cores", segundo Rey Morgan Longyear ${ }^{17}$.

A natural instabilidade do modo menor, usado agora com freqüência, conduz a cromatismos e harmonias alteradas. A influência da música eclesiástica (polifônica russa ou monódica francesa) e da música popular faz com que a modalidade se acentue na segunda metade do século XIX, em Dvorák, em compositores russos e outros. Essa nova linguagem harmônica corresponde, com mais propriedade, à sensibilidade e intensa vida interior do homem romântico.

\footnotetext{
${ }^{15}$ Apud. CHANTAVOINE, Jean \& GAUDEFROY-DEMONBYNES, Jean. El Romanticismo en La Musica Europea. México, Union Tipografia Editorial Hispano Americana, 1958, p. 258.

${ }^{16}$ CHANTAVOINE, Jean \& GAUDEFROY-DEMONBYNES, Jean, op.cit., p. 257.

${ }^{17}$ LONGYEAR, Rey Morgan. Nineteeth-century romanticism in music. New Jersey, Prentice-Hall, 1988 , p.17.
} 
1.5.3 Ritmo: Embora ligado ao tradicional período de oito compassos, ocorreu uma distensão rítmica. Liberdade e flexibilidade são os elementos que diferem o tratamento da música romântica do período anterior.

Medidas irregulares e complexas, conduzindo a frases com tamanhos e ritmos irregulares, surgiram também pelo crescente interesse pela música folclórica. A música do Leste europeu tem sido citada como a principal fonte de medidas irregulares.

Bruno Kiefer ${ }^{18}$ menciona a qualidade da "plasticidade rítmica" em detrimento da "racionalidade rítmica". Para ele, as inflexões no andamento através de rubatos, ou a própria construção rítmico-melódica com síncopes, acentuações no tempo fraco e outros recursos, levam à plasticidade do ritmo, favorecendo a descrição de estados emocionais.

1.5.4 Sonoridade: O som adquiriu um novo significado e valor. A sonoridade torna-se elemento inseparável da nova harmonia.

Também a exuberância sonora esteve presente no movimento romântico, no uso do pedal de sustentação do piano, na multiplicidade dos registros de oito pés do órgão e na orquestra, que praticamente triplicou de tamanho entre 1800 e 1914 . Maior número de instrumentos de corda foram introduzidos para contrabalançar um número maior de instrumentos de sopro, visando à homogeneidade sonora. Novas cores ou um clímax cada vez mais dramático foram obtidos por instrumentos de percussão mais numerosos.

1.5.5 Formas: Permanecem convencionais, porém, são dissolvidas por uma ilimitada variedade de melodias e ritmos, decorrentes de uma liberdade interior. Portanto, a forma não mais modela o conteúdo, como ocorria no Classicismo, mas

\footnotetext{
${ }^{18}$ KIEFER, Bruno. Elementos da Linguagem Musical. Porto Alegre, Movimento, 1987, p.36-37.
} 
sofre um processo de acomodação de um conteúdo expressivo, constituído por uma nova linguagem harmônica e melódica.

1.5.6 Frase de quatro compassos: freqüentemente utilizada já no século XVIII, com o objetivo de manter a regularidade na dança, pode ser introduzida por um ou dois compassos de acompanhamento e o compasso final pode ser estendido através de ecos.

Para Charles Rosen, ${ }^{19}$ a utilização sistemática da frase de quatro compassos, muitas vezes "transformou as pequenas peças em verdadeiras miniaturas".

${ }^{19}$ ROSEN, Charles. A Geração Romântica. São Paulo, EDUSP, 2000, p. 385-386. 


\subsection{A Natureza romântica}

O sentimento pela natureza e a imaginação pitoresca, concebida à maneira do pintor, sempre estiveram presentes na música, sendo freqüentes na época trovadoresca as pastourelles, serranillas, reverdies. Porém, seu uso como tema revela um apelo à natureza como valor supremo, que conforta e é repouso. Consolo para a infelicidade do homem que, antes das Revoluções Industrial e Francesa, via a natureza como um paraíso proibido e após o desenvolvimento da cultura urbana, como um bem perdido, segundo Alfredo Bosi. ${ }^{20}$

Para o artista romântico, a exaltação dos valores da natureza decorrentes da exacerbação da emotividade, faz da paisagem um verdadeiro "estado de alma". E no mundo natural, mesmo a "placidez do lago", a "serenidade do monte" ou o "ímpeto do vento" encarnam esses "estados".

A "pintura musical objetiva" de épocas anteriores transforma-se em "paisagem confidente", que transmuta os humores e emoções do artista em "paisagens interiores", reflexos da alma, transposição musical das emoções.

${ }^{20}$ BOSI, Alfredo. História Concisa da Literatura Brasileira. São Paulo, Cultrix, 1972, p. 65-66. 
Portanto, ao ser espelho, a obra romântica reflete quem a fez, levando o espectador a estabelecer um contato emocional direto com o artista, segundo Harold Osborne. ${ }^{21}$

No período romântico, o valor do detalhe, as diferentes nuances de luminosidade do pôr-do-sol ou de uma manhã de neblina passam a ter valor emocional tão intenso ou maior que o conjunto.

Para Giuseppe Gatt, ${ }^{22}$ "a adesão ao fenômeno particular comporta o abandono das vistas e dos panoramas, para concentrar-se sob uma só parte da natureza, cujo caracterizado microcosmos particular implica e revela a beleza e o mistério do macrocosmos universal”.

Ao contrário de épocas anteriores, poucas vezes o homem fará parte da paisagem romântica. Para isso, John Constable muito contribuiu, buscando conhecer a natureza pelo que ela é em si mesma e pelo que pode nos oferecer e ensinar.

A influência do estudo das montanhas, no final do século XVIII, vistas agora como criaturas orgânicas, também trouxe à paisagem o sentido de movimento, abrangendo passado e presente, transferindo ao estilo romântico uma realidade fluída, em constante alteração.

Nesta nova visão do mundo, a ansiedade, assim como a instabilidade, tornouse fonte de inspiração e embora os afetos parecessem efêmeros, eram mais intensos.

$\mathrm{Na}$ literatura, o triunfo da poética de paisagem e da prosa descritiva sobre a poesia épica ocorre entre 1795 e 1805 (Wordsworth, Coleridge, Goethe). A ênfase à

\footnotetext{
${ }^{21}$ OSBORNE,Harold. Estética e Teoria da Arte. São Paulo, Cultrix, 1968, p.182.

${ }^{22}$ GATT, Giuseppe. Constable. Barcelona, Ediciones Toray, 1968, p. 11.
} 
pintura de paisagem, em lugar da temática histórica e religiosa, estende-se da metade do século XVIII aos anos próximos de 1830 (Constable).

Na música, a descrição de um lugar específico ocorrerá com Álbum $d$ 'un voyageur (Liszt, 1835) e Liederkreis (Schumann, 1840).

Para Schiller ${ }^{23}$, o triunfo da poética e da pintura de paisagem, na verdade, foram inspirados pela música, indicando a possibilidade de uma criação artística que não tenha que se referir a algo que não seja ela própria.

Portanto, no período romântico, a emoção proveniente das belezas naturais é suficiente, através da imaginação, para a liberação de um estado lírico, que levará à produção da obra musical.

${ }^{23}$ ROSEN, Charles. A Geração Romântica. São Paulo, EDUSP, 2000, p. 198. 


\subsection{Música programática}

O conceito de música de programa foi estabelecido em 1700, com a publicação das seis sonatas Bíblicas de Johann Kuhnau, que dotadas de maior realismo descritivo, eram precedidas por um resumo do que a obra pretendia transmitir, assim como por frases durante o transcurso de cada sonata, indicando as intenções programáticas.

A expressão foi criada por Liszt, para designar uma música de caráter descritivo ou narrativo, acompanhada de um prefácio, que orientava o ouvinte para a idéia poética da obra. Para ele, a música pode representar indiretamente as coisas, sugerindo sua realidade emocional.

Elementos tais como motivos, modulações, retornos na música programática são determinados pelo tema que pretende descrever.

A música de programa romântica difere das tentativas de representações pictóricas de épocas anteriores, nas quais a sugestão era decorrente da imediata associação audível, que incluía tumulto de batalhas, repicar de sinos, sons de tempestades, canções de pássaros ou cenas no campo. Ela tem origem em um argumento originado pelo sentimento interno, pelo "eu mais íntimo" do músico e não 
de um argumento objetivo delineado previamente. Portanto, seria resultado de "uma necessidade espiritual subjetiva".

\subsection{Da suíte barroca à pequena forma romântica}

Nascida da dança e da canção, atividades humanas representativas de espontaneidade, "a suíte é a imagem da vida e de seus contrastes", segundo Daniel $\operatorname{Lesur}^{24}$. Forma favorita dos alaudistas e cravistas, consiste na justaposição de danças contrastantes, perdendo, em fins do século XVI, sua função coreográfica, impondo-se como forma instrumental.

Os alaudistas, por usarem um instrumento de difícil afinação, reuniram o maior número possível de peças no mesmo tom, mas com características rítmicas diferentes. Aos poucos, ocorreu a modificação dos ritmos de danças tradicionais e houve a preocupação de exprimir uma emoção ou um tema.

As suítes tiveram sua forma acabada com os cravistas franceses, que produziram um repertório rico em imaginação de pequenas peças descritivas com título sugestivo, especialidade de François Couperin. Essas composições chegaram às peças breves do repertório romântico, passando pelas Bagatelas de Beethoven.

\footnotetext{
${ }^{24}$ Apud. MANUEL, Roland. Plaisir de la Musique. Paris, Éditions du Soleil, 1947, p. 181.
} 
A maior parte das obras de Couperin tinha títulos com as seguintes características, segundo Jean \& Brigitte Massin: ${ }^{25}$

- eram dedicatórias às suas alunas: La Princesse de Chabeuil, La Meneton;

- sugeriam um caráter musical: La Ténébreuse, La Lúgubre, La Badine, L’Ingénue, L'Enjouée;

- descreviam um quadro da natureza ou representavam verdadeiros programas ou pequenas comédias da natureza: Le Rossignol en amour ( $O$ rouxinol apaixonado), Les Linottes effarouchée (Os pintarroxos assustados).

Em um de seus livros de Piéces de Clavecin, Couperin assim se expressa sobre seus títulos: "Sempre tenho um objeto presente ao compor estas peças (...) os títulos correspondem às idéias que tenho, e me desculparão por não dar conta delas (...) a maior parte destes títulos estão melhores nos amáveis originais que quero representar que nas cópias musicais tiradas delas". ${ }^{26}$

A relação palavra-som na música instrumental barroca - simples imitação sonora de ruídos de animais ou instrumentos musicais - é a forma mais primitiva utilizada na música para produzir idéias extramusicais.

Le Coucou de Daquin, La Poule de Rameau não evocam a natureza, mas são o resultado da imitação através do arabesco sonoro. Os timbres do clavicórdio eram propícios ao aspecto descritivo e as limitações dos instrumentos também levavam à necessidade de proporcionar um fundo harmônico através da repetição de notas, resultando na freqüência de timbres, grupetos, mordentes.

Portanto, Daquin, Couperin e Rameau concluem de forma perfeita uma época de gestação de breves peças instrumentais, que chegarão à pequena forma

\footnotetext{
${ }^{25}$ MASSIN, Jean \& Brigitte. História da Música Ocidental. Rio de Janeiro, Nova Fronteira, 1997, p. 376.

${ }^{26}$ Apud. SALAZAR, Adolfo. La Musica en la Sociedad Europea. México, El Colegio de Mexico, 1946, v.2, p. 228.
} 
romântica, exprimindo agora emoções pessoais. E se o título simplesmente indicava um caminho para o processo de criação, com o Romantismo passa a assinalar o rumo que a imaginação do ouvinte irá seguir para a apreciação da obra, como comenta Adolfo Salazar. ${ }^{27}$

${ }^{27}$ SALAZAR, Adolfo. Forma y Expresion en la Musica. México, El Colegio de Mexico, 1941, p.118. 


\section{Capítulo 2: O PIANO E A PEQUENA FORMA MUSICAL}

\subsection{O piano: importância e conseqüências da descoberta de suas plenas possibilidades}

O piano está indissoluvelmente ligado à evolução da música romântica, refletindo intensamente seu caráter. Por seus muitos recursos sonoros, expressou claramente os sentimentos dos compositores da época. A plena descoberta das possibilidades desse instrumento coincidiu com o início do Romantismo, período em que a individualidade do piano passa a ter um papel preponderante.

No século XIX, o aprimoramento das novas técnicas de fabricação dos instrumentos fez com que suas possibilidades fossem aumentadas e sua execução facilitada. O piano passou por diversos melhoramentos, e o conseqüente processo de industrialização permitiu sua ampla difusão.

O progresso do piano, nesse período, caracteriza-se pela multiplicidade de pesquisas e aperfeiçoamentos que dizem respeito tanto à forma e dimensões, como à estrutura.

Duas importantes melhorias nele foram feitas: chapas mais resistentes e a conseqüente extensão do teclado. Pierre Boulez ${ }^{28}$ afirma que “(...) foi a indústria do aço que permitiu a fabricação do piano moderno, o que significou um instrumento com a tensão de cordas maiores, com uma tábua harmônica mais forte, capaz de resistir a essa tensão. Resultou que a sonoridade ampliou-se (...)".

${ }^{28}$ BOULEZ, Pierre."Encontro com Pierre Boulez". In: Revista Música. São Paulo, 1996, v. 7, n. 1/2, p. 200-218. 
Posteriormente, o sistema de cordas cruzadas distribuiria diagonalmente os grupos de cordas sobre a chapa, resultando em maior ressonância. Também os martelos, antes de couro, são agora maiores e passam a ter revestimento de feltro.

O sofisticado mecanismo do "duplo escape", ao impedir que o martelo voltasse a ferir a corda que havia acabado de percutir, resultou na rapidez da repetição de uma mesma nota e na diminuição do esforço necessário para colocar em ação o martelo.

A revolução estilística ocorrida no século XIX está intimamente relacionada às novas técnicas de utilização do pedal. Sua função de sustentar as notas golpeadas e permitir que outras que não o foram vibrem por simpatia e as possibilidades de gradações do toque distinguem o piano de todos os outros instrumentos.

Espera-se do piano, nas obras dos compositores românticos, que soe de maneira constante, modelando as frases pelas alterações das vibrações totais. Todos esses melhoramentos contribuíram para novas possibilidades em termos de efeitos sonoros, de cor, registro, volume e versatilidade no que diz respeito ao toque.

Se o piano exerceu importante papel nas incursões dos músicos da época, foi com Chopin que adquiriu uma função específica quanto ao aspecto expressivo. Revolucionando a técnica pianística não só pelas obras compostas, mas pelos efeitos de interpretação delas resultantes, Chopin prosseguiu com a revolução pianística esboçada por Beethoven, contribuindo para a instauração do piano moderno.

Com o objetivo de dar perfeita autonomia aos dedos, seus Estudos exploram basicamente todas as possibilidades do instrumento. Muitos dos problemas técnicopianísticos são abordados de forma bem ousada. 
Recursos nunca oferecidos por um instrumento até o período foram obtidos com Liszt. Em seu artigo de 1837, escrito na Gazeta Musical, ele comenta sobre o piano: "Podemos tocar os acordes como uma harpa, cantar como os instrumentos de sopro, destacar, ligar, realizar nele mesmo milhares e milhares de passagens completamente diferentes, que antes resultavam possíveis somente com a ajuda de vários instrumentos $(\ldots)^{29, "}$.

Também o piano pode ser considerado não só um instrumento solista, de virtuosidade, mas um elemento de prospecção, "um meio de contato com a realidade musical”, como menciona Tchaikovsky. ${ }^{30}$

Fatores de ordem técnica, social e arquitetônica estão ligados à difusão do piano. Em torno dele, a música começa a instituir-se. Cada vez mais presente nos lares burgueses, também foi favorecido pelas novas condições acústicas criadas nas grandes salas, abertas a um público cada vez mais numeroso.

Segundo Adolfo Salazar ${ }^{31}$, o piano converteu-se, desde Schumann, Chopin e Liszt, "em um microcosmos frente ao macrocosmos das forças dinâmicas e de cor que é a orquestra". Interpretar agora consiste em "fundir as sonoridades, as dissonâncias que ficam sem resolução ou que se resolvem por evaporação", resultando numa "atmosfera luminosa". Nela todas as nuances dependem da habilidade do executante que, por meio de sua sensibilidade tátil, irá valorizar cada elemento, destacando ora uns, ora outros, com a colaboração do jogo de pedais, menciona o autor.

Portanto, as novas formas de expressão musical são agora decorrentes não só do estilo romântico, mas das possibilidades facultadas pelo piano.

\footnotetext{
${ }^{29}$ CASELLA, Alfredo. El Piano. Buenos Aires, Ricordi Americana, 1946, p. 67.

${ }^{30}$ MANUEL, Roland. Plaisir de la Musique. Paris, Ėditions du Seuil, 1947, p. 99.

${ }^{31}$ SALAZAR, Adolfo. Conceptos fundamentales en la história de la música. Madrid, Alianza Editorial, 1988, p. 208.
} 


\subsubsection{Cantabile}

Aumentar e manter a intensidade sonora no piano sempre foi uma preocupação de compositores e intérpretes. Diferentemente dos instrumentos de cordas e sopros, que têm na voz humana um modelo para o cantabile, o piano possui, como característica, total independência referente à vocalização. Através de melodias que valorizavam a freqüência das emissões sonoras, os compositores, a partir de Clementi, empenharam-se para obter o cantabile. Mais tarde, os executantes se dedicaram à consecução de uma sonoridade plena, expressiva, intensa.

É necessário ressaltar, no aspecto cantabile, a importância do toque e encontrar um equilíbrio sonoro entre intensidade e sensibilidade, através da flexibilidade e liberdade de movimentos dos dedos, pulso e antebraço. Também é preciso considerar os melhoramentos ininterruptos dos instrumentos, responsáveis pela importante evolução do cantabile pianístico.

\subsubsection{Virtuosismo}

Não sendo elemento desconhecido nos séculos anteriores, o virtuosismo reaparece, no teclado, no final do século XVIII, em decorrência do aperfeiçoamento dos instrumentos e relacionando-se com o crescimento contínuo de um novo público.

As inovações no campo da virtuosidade, iniciadas por Muzio Clementi (17521832), prosseguem com Cramer, Hummel, John Field, Kalkbrenner, Moscheles, Czerny, influenciando toda a geração romântica. Com obras didáticas ou técnicas, 
enfatizam problemas tais como escalas em terças, sextas, oitavas quebradas, oitavas na mão esquerda ou nas duas mãos simultaneamente.

O virtuosismo técnico romântico tinha por objetivo não só explorar todos os recursos do instrumento, mas também manifestar as exacerbações do ego, que dizem respeito não só ao artista, mas à liberdade técnica que, como criador, necessita a fim de realizar sua obra. Antes que o recital se estabelecesse, o piano virtuosístico influenciaria o "concerto" com orquestra.

Os efeitos causados pelos concertos de Paganini proporcionarão significativas alterações na escrita pianística e no desempenho dos grandes virtuoses que tentarão, com seus instrumentos, obter os mesmos resultados conseguidos pelo violinista. Os doze Estudos op. 10 de Chopin são escritos sob essa influência, o mesmo ocorrendo com os Estudos Transcendentais e, sobremaneira, os Etudes d'après Paganini de Liszt. Não se deve esquecer da contribuição de Alkan nesse desiderato virtuosístico.

A música virtuosística, antes concebida prioritariamente do ponto de vista da execução, adquire valores novos referentes à exploração das possibilidades sonoras, assim como numa visão voltada ao colorido e à intensidade. Dessa forma, a distinção entre a peça intimista, poética, própria do salão burguês, da peça virtuosística, que resultará no recital, é cada vez mais nítida. Decorrente do estilo de vida da sociedade do período, essa dicotomia torna-se um elemento decisivo na música romântica. 


\subsection{Conceito de forma}

Para Roland Manuel ${ }^{32}$, a forma é a tradução material e visível de uma ordem interna, oculta. Remete a uma organização estética das idéias musicais, sendo que a essência da forma está no espírito criador e não no aspecto externo. Equivale ao conceito de "forma abstrata" de Riemann ${ }^{33}$ (estrutura interna de uma composição) contida em uma "forma concreta" (configuração global que expressa a identidade, como suíte, sonata, cantata). Ou ainda, às "formas musicais propriamente ditas", contidas nos "gêneros musicais", terminologia preferida por Jean \& Brigitte Massin ${ }^{34}$.

O termo forma é também utilizado para indicar o número de partes, como nas expressões "forma binária", "forma ternária".

Grande número de obras utiliza a forma ternária ABA. Para a seção contrastante, a harmonia é o fator primordial. A terceira parte é, por vezes, uma repetição exata da primeira, mas pode ser modificada. A repetição confirma, através da memória, a percepção daquilo que foi agradável.

As "formas abstratas" raramente são o resultado de fatores socioculturais, mas podem ser uma tentativa deliberada de renovar as técnicas de composição.

As "formas concretas" são historicamente importantes, pois expressam uma cultura coletiva e um comportamento estético geral, revelando os gostos e os costumes de uma época. Por esse motivo, não permaneceram imutáveis através dos tempos. Ocorreu sempre um período de gestação, nascimento e crescimento dos tipos formais, cuja história nunca será definitivamente encerrada, pois, com

\footnotetext{
${ }^{32}$ MANUEL, Roland. Plaisir de la Musique. Paris, Éditions du Seuil, 1947, p. 274.

${ }^{33}$ Apud CANDÉ, Roland. História Universal da Música. São Paulo, Martins Fontes, 2001, v. 1, p. 505.

${ }^{34}$ MASSIN, Jean \& Brigitte. História da Música Ocidental. Rio de Janeiro, Nova Fronteira, 1997, p.72.
} 
freqüência, antigas formas são resgatadas por compositores, visando a uma nova aparência.

Porém, após o amplo movimento romântico, tanto na música quanto na literatura, houve um afastamento gradual das características de certos gêneros e obras, como o noturno, o estudo, a rapsódia, que não se enquadravam em um gênero estritamente estruturado.

No piano, surgem as pequenas formas livres, isoladas, como os Improvisos, Momentos Musicais ou simplesmente Klavierstücke de Schubert, ou ainda uma sucessão de peças como o Carnaval e Kreisleriana de Schumann, ratificando a preferência dos românticos pelo que é único, original. As formas consagradas pela tradição, como as sonatas, tornaram-se universais, racionais, portanto, inadequadas à expressão de momentos únicos.

Ocorre aqui a mesma estética romântica que substitui, na literatura, longos poemas épicos ou didáticos por coletâneas de poemas, como Les Contemplations, de Victor Hugo.

Portanto, é possível considerar o freqüente caráter fragmentado, fracionado da arte romântica, como decorrência da tentativa de captação fugaz de algo momentâneo, não apreendido em sua totalidade; algo que não se enquadra nos limites da forma, por buscar, sempre e incessantemente, o infinito. 


\subsection{A pequena forma pianística}

As sucessivas gerações românticas privilegiam a pequena peça como a forma mais apropriada às suas necessidades expressivas e influenciam o repertório pianístico até o início do século $\mathrm{XX}$, podendo ter, segundo José Eduardo Martins ${ }^{35}$, características intimistas, visar ao efeito exterior, ou ter função didática.

A forma-sonata, cada vez mais rara, agora restrita à música de câmara ou sinfônica, confirma o desconforto em relação às grandes formas, proveniente do descrédito nos sistemas racionais do século XVIII.

No momento em que priorizam a necessidade expressiva, podemos afirmar que essas obras:

- favorecem a criatividade melódica e harmônica, por não seguirem formas fixas;

- a concisão resulta na multiplicidade de novas experiências estéticas, o que as transforma em verdadeiros laboratórios musicais;

- possibilitam a liberdade de expressão dos sentimentos pessoais, caracterizando nitidamente o espírito individualista romântico;

- captam o instante psicológico ou dramático, resultando, muitas vezes, na justaposição de elementos.

As peças curtas podiam ter títulos descritivos, remotamente relacionados às peças do período barroco, porém, exprimindo emoções pessoais, próprias do espírito romântico, adequado a um novo instrumento.

\footnotetext{
${ }^{35}$ MARTINS, José Eduardo. Henrique Oswald: Compositor Romântico.Tese de Doutorado. São Paulo, FFLCH-USP, 1988, v.2.
} 
Outros nomes de composições surgiram, como Momento Musical, Noturno, Romance sem palavras, Balada, Improviso, Peças líricas, Folha d'álbum. Também surgiram danças com pulsação característica, como a valsa e a mazurca.

Numerosas obras apresentam, como estrutura, a forma ABA', sendo A' uma repetição modificada da primeira parte, na qual a tonalidade é apresentada. A parte B, contrastante, tem como elemento fundamental a harmonia, sendo que nas pequenas obras, as inovações ocorrem nos detalhes. Portanto, o caráter de novidade não está na estrutura, mas no conteúdo musical romântico, no sentimento.

A única forma completamente nova do Romantismo foi o estudo, que apresenta, como interesse musical, uma determinada dificuldade técnica, sendo a própria mão a origem do processo criativo. O delineamento dos compassos iniciais, no estudo, geralmente prossegue até o final, ocorrendo uma perfeita identidade entre uma idéia musical e sua concretização.

As Bagatelas de Beethoven, escritas ao longo de quase vinte e cinco anos (de 1797 a 1823), representam diferentes fases do processo criativo do compositor. François Couperin, em publicações de 1716, já incluíra um pequeno rondó intitulado Les Bagatelles, termo empregado posteriormente por Beethoven para designar uma série de peças. Principalmente as de op. 119 e op. 126 já antecipam as estruturas rítmicas e de frase das pequenas peças românticas, repletas de emoção, que passaram a ser compostas por músicos intimistas de toda a Europa.

John Field (1782-1837), criando os Noturnos, foi um marco importante da peça delicada, intimista, de constante interesse lírico.

Ao mesmo tempo, os tchecos Tomaschek e Worzischek criaram peças de efeito agradável, como Rapsódias e Improvisos, unindo sentimentalismo com as peculiaridades dos países centro-europeus. Essas obras chegaram a Schubert, 
Mendelssohn, Chopin, Schumann, Liszt, os quais, na primeira metade do século XIX, propagaram a pequena peça de forma livre ou proveniente de dança.

Os Momentos Musicais de Schubert foram a base da miniatura musical, gênero do qual surgiram tantas pequenas grandes obras de características semelhantes, como Peça lírica e Folha d' álbum ${ }^{36}$. Embora não tenha sido o inventor dessas formas, Schubert "iluminou” esse gênero, seguido por sucessivas gerações.

Nos Improvisos e Momentos Musicais, Schubert utiliza a mesma concisão e lirismo dos lieder, criando verdadeiros poemas musicais. A liberdade dessas obras não exclui um certo plano estrutural, pois quase sempre possuem uma parte central semelhante ao trio de um minueto.

A grande quantidade de peças que Schubert compunha, "páginas soltas que escrevia para dar prazer a suas infinitas amizades" ${ }^{37}$, eram reunidas em séries ou coleções.

As Canções sem palavras de Mendelssohn, reunidas em oito volumes, foram escritas ao longo de vários anos, em seus raros momentos de recolhimento. Consistem em peças essencialmente melódicas, que apresentam longos temas. Apesar da utilização relativamente nova da pequena forma, as Canções sem palavras não são inovadoras quanto à linguagem e estrutura.

A preferência de Schumann pelas pequenas formas é a escolha de um poeta lírico, sendo que o piano tornou possível sua dupla realização, na poesia e na música. "O Romantismo não está na forma, se o compositor for poeta, ele também irá expressar-se como tal”, diz Schumann. ${ }^{38}$ A maior parte de sua obra pianística consiste em uma série de pequenas peças ou variações, cuja mudança constante de

\footnotetext{
${ }^{36}$ ZAMACOIS, Joaquin. Curso de Formas Musicales. Barcelona, Idea Books, 2002, p. 235.

${ }^{37}$ SALAZAR, Adolfo. Conceptos Fundamentales en la história de la música. Madrid, Alianza Editorial, 1988, p. 201.

${ }^{38}$ MASSIN, Jean \& Brigitte. História da Música Ocidental. Rio de Janeiro, Nova Fronteira, 1997, p.724.
} 
estilo faz do ritmo um elemento essencial. Nelas, a brevidade da forma intensifica o tom de confidência.

O desenvolvimento da pequena forma relaciona-se com a poesia e a literatura da época. O conceito de fragmento literário, que para Schlegel deveria ser "completo em si mesmo e separado do restante do Universo"39, influenciou outras formas artísticas, resultando na elaboração de grande número de coletâneas musicais.

Os Prelúdios op. 28 de Chopin são um nítido exemplo de um conjunto de fragmentos reunidos unicamente pelo processo de adição, com exceção do último, que finaliza o conjunto. Sua predileção pelas formas breves, que estimulam sua imaginação, inclui títulos genéricos, próprios do período romântico, como Barcarolas, Improvisos, Noturnos e danças.

Liszt, através da expressividade e maior dificuldade técnica, eleva a peça breve ao nível da música de concerto. Também em seu conjunto de peças intitulado Annés de Pélerinage (1839), descreve os lagos suíços e os jardins italianos, conduzindo o ouvinte para os locais onde estivera.

A música romântica para piano, de caráter individualista, visava exprimir os sentimentos pessoais do compositor, assimilados por uma nova platéia nos recitais. Era executada em saraus aristocráticos, em salas de concerto freqüentadas pela burguesia ou em reuniões familiares, onde amadores e profissionais apresentavamse alternadamente. As peças para piano estavam presentes nos programas, juntamente com alguma grande sonata. ${ }^{40}$ As apresentações familiares serviam para a divulgação de novas obras, que logo teriam sua aceitação testada.

\footnotetext{
${ }^{39}$ Apud ROSEN, Charles. A Geração Romântica. São Paulo, EDUSP, 2000, p. 88.

${ }^{40}$ MARTINS, José Eduardo. Henrique Oswald: Compositor Romântico. Tese de Doutorado. São Paulo, FFLCH-USP, 1988, v.2. p. 374
} 
Segundo Adolfo Salazar ${ }^{41}$, a necessidade de expressão do espírito romântico leva ao aprimoramento dos instrumentos, os quais, por sua vez, enriquecem a produção musical. Isso ocorreu principalmente com o piano, que tendo sido aperfeiçoado no mais alto grau, desencadeou uma numerosa produção de peças breves, explorando a expressividade e os diferentes planos sonoros.

Por volta da metade do século XIX, desenvolve-se progressivamente um novo conceito social e o individualismo assume importante papel. Baseando-se nos cantos e danças populares, criam-se obras líricas inspiradas em temas nacionais, que evocam a tradição de um país e o caráter de seus habitantes. Assim, nascem as escolas nacionais, quase simultaneamente em diversos países da Europa, e com elas, a diversidade da pequena peça se multiplica, notadamente com obras de compositores da França, Espanha, Noruega, Rússia.

Portanto, a produção musical das últimas décadas do século XIX e início do século XX deriva diretamente da pequena forma pianística - expressão viva da época - apreciada por sua intensidade emotiva e sensações, refletindo uma linguagem essencialmente pessoal.

\subsection{Nacionalismo: a pequena forma como veículo de expressão}

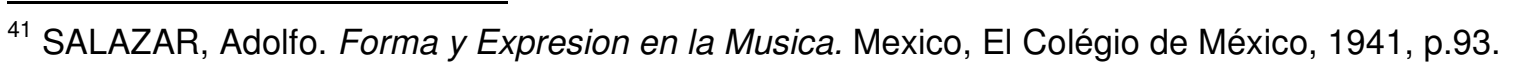


O Nacionalismo musical consistiu na busca de identidade nacional por parte dos países sedimentados ou daqueles que acabavam de alcançar a independência, buscando estes, doravante, a valorização de características até então reprimidas ou desconhecidas. Reação natural aos elementos aristocráticos da música clássica, procurou resgatar, entre outros atributos, as manifestações do homem do campo e da cidade.

Já no final do século XVIII, melodias folclóricas, na acepção da música elaborada artisticamente, passaram a ser incorporadas às obras dos compositores, ocorrendo em meados do século XIX, uma tentativa mais consciente para difundir e valorizar os elementos nacionais.

Adolfo Salazar ${ }^{42}$ enfatiza o aspecto passivo do elemento nacional, que é transformado em força dinâmica através da ação política nacionalista, reagindo contra os caracteres próprios do século anterior. Portanto, o Nacionalismo é visto, na arte, como uma decorrência dos nacionalismos políticos.

Ao mesmo tempo em que ocorreu a busca de uma arte com peculiaridades nacionais, a maior facilidade de divulgação dessas composições proporcionou também uma universalização dessas obras, como enfatiza Kurt Pahlen ${ }^{43}$ : "Mas no mundo das estradas de ferro, e do tráfico que cada mais mais se faz, é na música que vemos claramente que surge nova internacionalização a eliminar o nacionalismo musical".

A expressão musical nacionalista se faz presente:

\footnotetext{
${ }^{42}$ SALAZAR, Adolfo. La Musica en la Sociedad Europea. México, El Colégio de México, 1946, v.4, p.342.

${ }^{43}$ PAHLEN, Kurt História Universal da Música. São Paulo, Melhoramentos, 1945, p.177.
} 
- na busca de cantos e danças especialmente do homem do campo, elemento representativo do solo;

- na criação de obras líricas inspiradas em temas nacionais;

- na evocação de instrumentos populares;

- na emancipação modal (modos de cantochão, em particular).

A partir do exemplo de Weber, que se empenhou em obter uma ópera genuinamente alemã, com enredos facilmente assimilados pelo povo, as chamadas "escolas nacionalistas" despertaram não só países que até então pouco haviam contribuído com a música do Ocidente, como Polônia, Rússia, Noruega, como proporcionou um verdadeiro renascimento musical em nações que já haviam desempenhado importante papel no transcorrer da história da música, como a Espanha.

As "escolas nacionalistas" não criaram nenhum novo tipo de forma e a pequena peça pianística continua refletindo não só as características do compositor, mas também do próprio país, expressando os mais diversos ritmos, melodias e efeitos instrumentais.

\subsubsection{Rússia}




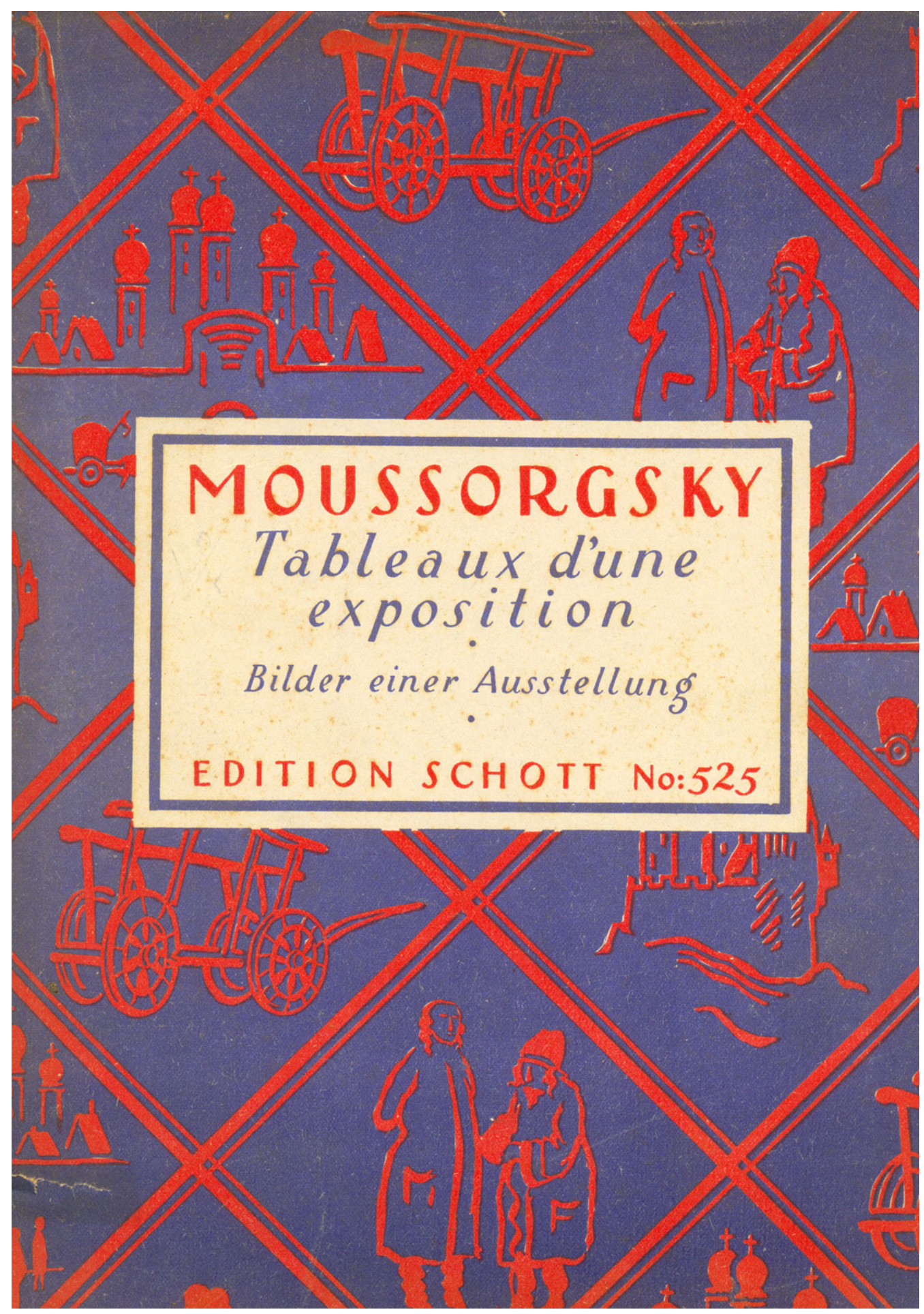

A música artística russa aparece pela primeira vez no século XIX, marcada pela criação de uma ópera nacional, e seu florescimento foi facilitado pela presença, na literatura, de nomes como Gogol, Tolstoi e Dostoievsky. Foi precedida pela 
música religiosa, contendo elementos de Bizâncio, e por uma música popular, que alterna um ritmo vibrante com certa melancolia, que, segundo Kurt Pahlen ${ }^{44}$, "parece ser um 'reflexo da paisagem das estepes infinitas, dos grandes rios, florestas e pântanos impenetráveis, das desalentadoras extensões de neve' “.

A nação russa visava, na verdade, a uma emancipação cultural e artística, reagindo contra uma arte estrangeira, apoiada pelas camadas aristocráticas.

Glinka aparece como chefe de escola e empregou não só motivos e ritmos russos, mas também elementos da música sacra eslava. Embora suas obras apresentem motivos populares ainda empregados de maneira instintiva, exerceu influência determinante nas gerações seguintes.

A utilização do folclore transformou-se em norma a partir do Grupo dos Cinco, nome a eles atribuído pelo crítico russo Vladimir Stassov. Demonstrando interesse pelo passado histórico, pelos costumes e pela Igreja ortodoxa russa, Balakirev, César Cui, Mussorgski, Rimski-Korsakov e Borodine empenharam-se em obter uma música especificamente russa, mais propensa à evocação do que à expressão pessoal.

Jacques Stehman ${ }^{45}$ comenta que os elementos descritivos utilizados por esses compositores contrastam com a música de caráter psicológico tão freqüente no Ocidente e aproximam os "quadros" por eles pintados, dos ícones tão comuns na cultura russa.

\footnotetext{
${ }^{44}$ PAHLEN, Kurt. História Universal da Música. São Paulo, Melhoramentos, 1965, p.81.

${ }^{45}$ STEHMAN, Jacques. História da Música Européia. São Paulo, Difusão Européia do Livro, 1964, p. 215.
} 


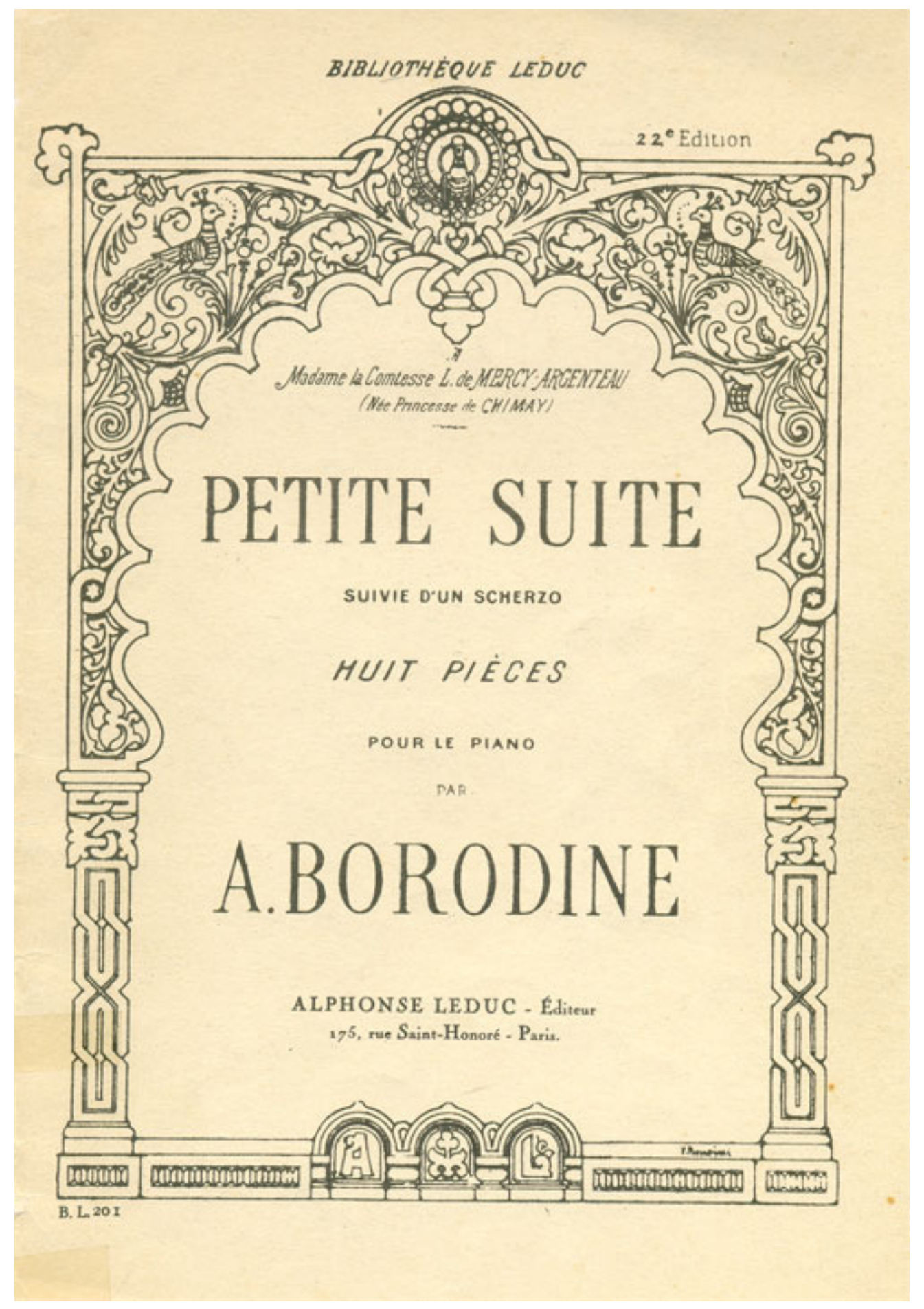

Na obra Tableaux d'une Exposition (1873), Mussorgsky demonstra sua capacidade de realizar uma "pintura musical", inspirando-se nos desenhos do arquiteto Viktor Hartman, seu amigo, que acabara de falecer. Consiste em uma série 
de dez peças, contendo cada uma o mesmo título do quadro que a inspirou. A introdução e os interlúdios intitulados Promenades representam os pensamentos e emoções do compositor no seu percurso entre um quadro e outro.

Em várias outras pequenas obras, tais como Au Village, En Crimée, Méditation, Une Larme, Intermezzo, La Jongleuse, é possível captar o estilo de Mussorgsky.

Também Borodine, sob o título de Petite Suite (1885), reúne peças curtas de musicalidade delicada, entre elas Intermezzo, Sérènade, Nocturne, precedidas pelos inusitados sonoros de Au Couvent, que inicia a obra. Temas e fragmentos melódicos de algumas peças podem ser reconhecidos em danças da ópera Príncipe Igor.

Embora Tchaikovsky não seja considerado adepto do Nacionalismo e utilize predominantemente temas comunicativos, a maneira de incorporá-los na frase e o perfil rítmico de sua obra lhe dão um caráter profundamente nacional, segundo Igor Stravinsky ${ }^{46}$. Entre as suas composições para piano, destaca-se a coletânea intitulada Les Saisons, escrita entre 1875 e 1876 para o informativo mensal Nouvellist. Acompanhadas, no original, de uma citação poética condizente com o título, de autoria de Puschkin, Maikow,Tolstoi, entre outros, as doze peças referemse a temas e atividades típicas dos meses do ano.

\subsubsection{Noruega}

Dentre os países escandinavos, a Noruega destacou-se em sua busca por fontes folclóricas, por aguardar sua independência da Suécia (foi a ela anexada em

\footnotetext{
${ }^{46}$ STRAVINSKY,Igor.Poética Musical em 6 Lições. Rio de Janeiro, Jorge Zahar, 1996, p. 77.
} 
1814) e por possuir uma música popular extremamente viva, como o halling e o springar, acompanhada de instrumento próprio, o hardangerferle.

Embora inicialmente influenciado por Schumann, Grieg (1843-1907) escreve sua primeira obra com características nacionalistas em 1865, Humoresques op.6, coletânea de cenas da vida popular. Também em outras obras deixa transparecer seu gosto pela natureza: fiordes e regiões solitárias são descritas e nelas habitam heróis, anões e gnomos, em melodias e ritmos inovadores.

Os dez cadernos das Pièces Lyriques representam importante parcela de suas composições para piano. Um total de sessenta e seis pequenas peças reunidas posteriormente em único volume foram compostas em diferentes fases de sua vida. Iniciadas por uma Ariette, o seu tema retorna em ritmo de valsa sob o nome de Souvenirs, peça que encerra a coletânea e dá à obra um sentido de unidade.

As Pièces Lyriques consistem em recordações, descrições musicais, estados psicológicos, que trazem os mais variados títulos: Le Ruisseau, Vers la patrie, Feuille d'album, Mystère e outros. Verdadeiros poemas de circunstância, ou ainda "confissões delicadíssimas", como menciona Paul de Stoeklin ${ }^{47}$.

\footnotetext{
${ }^{47}$ STOEKLIN, Paul de. Vida de Grieg. São Paulo, Livraria Cultura Brasileira, s.d., p. 71.
} 


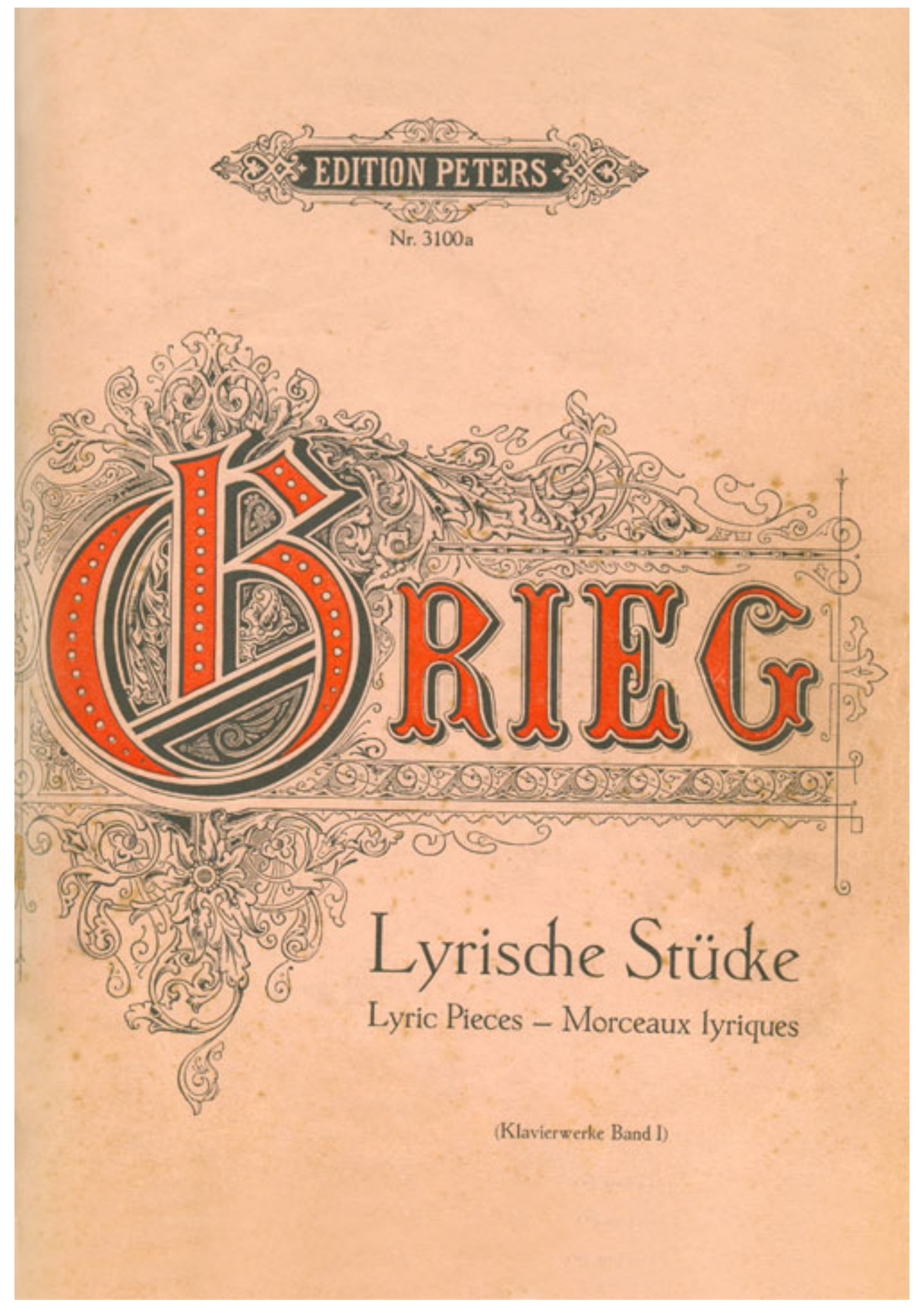

\subsubsection{Polônia}


Michael Kleophas Oginski (1765-1833) já utiliza ritmos folclóricos em suas obras, mas é Chopin quem transforma as mazurcas em importante campo de pesquisa. Escritas em Paris, essas obras consistem em uma nostálgica recordação da Polônia, repleta de elementos não utilizados na música européia.

Chopin escreveu cinqüenta e uma mazurcas, sendo que a em sol menor (op. 67, ํํㄹ) e a em fá menor ( op. 68 № 4) constituíram suas últimas composições. A diversidade dessas obras é explicada por suas características melódicas, rítmicas e harmônicas: em algumas ocorre a valorização do elemento rústico, outras são bastante melódicas. Há ainda as que se assemelham a elegias, como a op. $17 \mathrm{n} 1$.

É possível acompanhar, nessas obras, a gradativa evolução estilística do compositor e conhecer suas incursões no terreno da tonalidade.

\subsubsection{Tchecoslováquia}

O nacionalismo tcheco esteve diretamente relacionado ao desejo de libertação do domínio austríaco e os cantos populares há muito expressavam essa intenção. Smetana e Dvorák são nomes representativos desse movimento.

Assimilando profundamente os caracteres folclóricos, Dvorák incorpora-os em sua música e eles continuarão presentes em Janacek e Bartók. Em grande parte de suas obras, o elemento nacional é expresso não só através de melodias e ritmos eslavos, mas também por um certo lirismo próprio da cultura popular tcheca.

Dvorák escreveu numerosas peças para piano, entre elas oito Humoresques, (a sétima é particularmente famosa por sua transcrição para violino, feita por Kreisler) e as Silhouettes, coletânea de doze pequenas peças escritas sobre um mesmo tema. 


\subsubsection{Espanha}

Após importante período de florescimento musical no século XVI, com nomes como Victoria, a Espanha redescobre, na segunda metade do século XIX, um rico patrimônio de música popular, no qual elementos latinos e árabes dão origem a melodias e ritmos típicos, há muito esquecidos, em detrimento da música italiana.

Albeniz e Granados expressaram, através de meios apropriados, as características da música popular, do clima e do temperamento do povo espanhol. Pequenas peças típicas, danças, rapsódias tipicamente espanholas foram escritas por Albeniz, assim como as miniaturas da Suíte España e a Suite Iberia, sua obraprima, onde o compositor realiza uma verdadeira renovação da escrita pianística.

Também Granados, em suas Danzas españolas e em Goyescas, introduziu elementos tipicamente espanhóis, como o arabesco. 


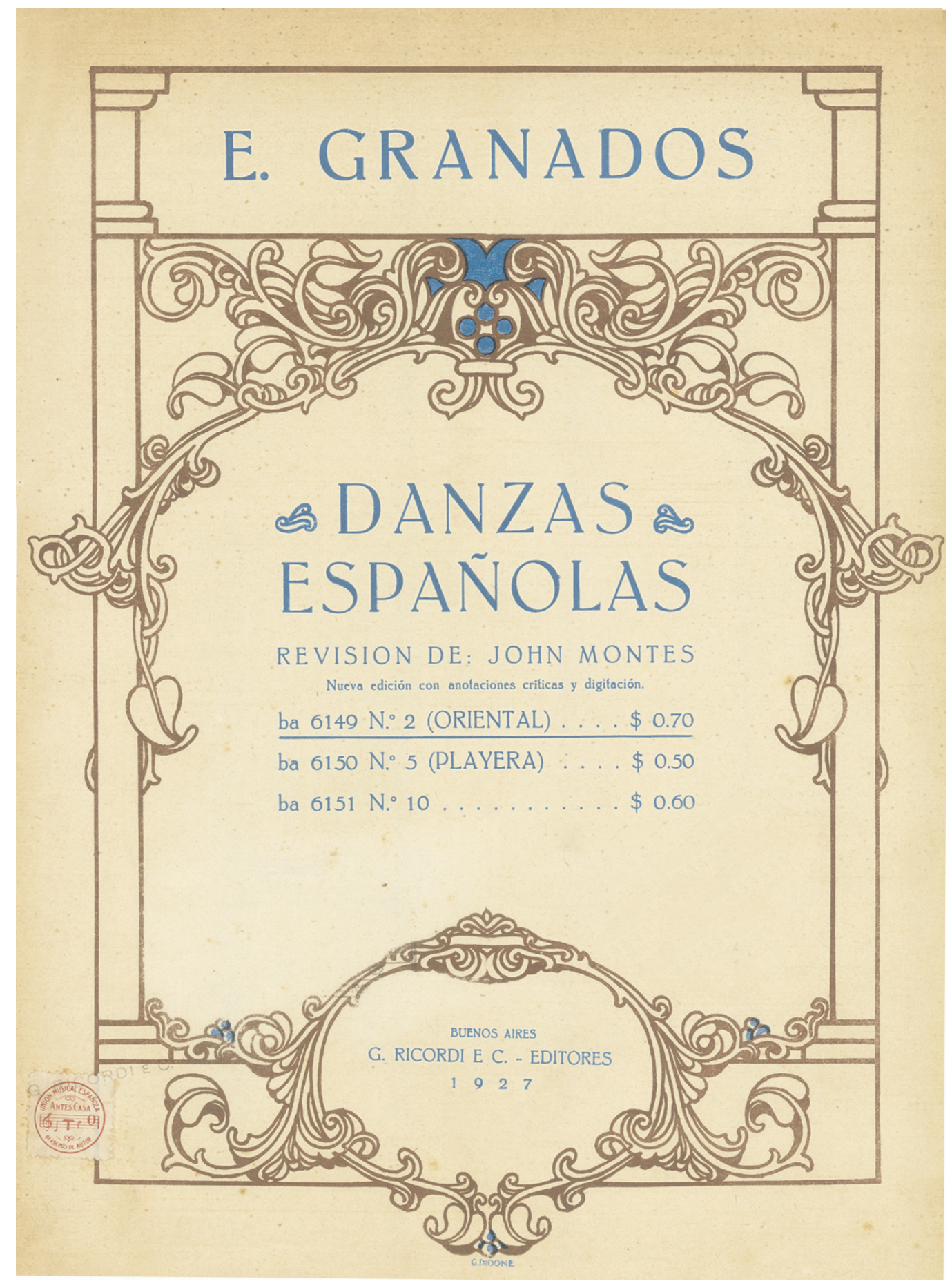


Além de compositor e regente, Francisco de Lacerda destacou-se como conferencista e estudioso do folclore português. Ainda jovem, parte para Paris, recebendo influência de Satie, Ravel e Debussy.

A peça Danse du voile para piano, premiada em um concurso promovido pela Revue Misicale, representa importante marco em sua vida.

Como coletânea, a obra Trente-six histoires pour amuser les enfants d'un artiste, constituída por miniaturas musicais, é considerada sua obra pianística mais importante. Escrita ao longo de várias décadas, foi retomada em diferentes épocas de sua vida. Embora existam nela momentos de descrição precisa, há o predomínio da evocação.

A obra caracteriza-se pela capacidade de concentração do discurso musical, teor poético, programatismo e a presença de conteúdos específicos do Simbolismo.

\subsubsection{França}

César Frank, nascido na Bélgica, em Liége, ocupa importante lugar na história do Romantismo, por sua contribuição a determinadas estruturas da linguagem musical.

Quanto à tendência em se considerar a música religiosa o verdadeiro domínio de César Frank, seu filho, Jorge César Franck, escreve:

“(...) Em realidade meu pai tem cultivado todos os gêneros. Músico consumado, foi um mestre em todas as formas de composição. Escreveu música religiosa e música profana, melodias, danças, pastorais, oratórios, poemas sinfônicos, sinfonias, sonatas, trios, óperas. Não manifestou sua personalidade em uma obra mais que em outra, mas em todas se entregou inteiramente". ${ }^{48}$

${ }^{48}$ ABBIATTI, Franco. História de la Musica. México, Union Tipografia Editorial Hispano Americana, 1960, p. 647. 
As dezoito Petites Pièces, introduzidas pela encantadora Les plaintes d'une poupée, exemplificam suas composições na pequena forma pianística.

Segundo Roland de Candé $^{49}$, as características estéticas nacionais francesas são encontradas mais facilmente na música de Chabrier e Fauré: "equilíbrio, ironia, comedimento e uma certa lucidez, que os franceses chamam de espírito".

Ao utilizar em suas obras ritmos e modos próprios da música popular, Chabrier consegue obter uma certa "ingenuidade requintada". Suas Pièces pittoresques para piano (1881), uma de suas principais obras, apresentam uma harmonização bastante pessoal.

Debussy, nacionalista convicto sob os mais diversos aspectos, quando compõe, cria novos parâmetros ligados ao timbre, à sonoridade e ao simbolismo expresso e suas obras resultariam, em parte, do conceito que dele se tem: ter sido o mais francês dos franceses.

Suas composições já não mais traduzem os sentimentos humanos, não representam íntimas confissões, tampouco expressam estados psicológicos. O valor sonoro, que resulta da evocação da natureza, luzes e cores, passa a substituir o elemento expressivo.

Utilizando modos da antiga música sacra, escalas eslavas ouvidas na Rússia e escalas orientais, Debussy incitou compositores de outros países a empregar escalas musicais próprias do folclore de suas nações.

A dissolução dos elementos principais da música (melodia, harmonia, ritmo) ocorre paralelamente à dos elementos básicos da pintura na arte de Cézanne, Renoir, Monet.

\footnotetext{
${ }^{49}$ CANDÉ, Roland, de. História Universal da Música, v.2. São Paulo, Martins Fontes, 2001, p.147.
} 
Para Jacques Stehman ${ }^{50}$, a mesma necessidade de libertação está presente em movimentos como o Naturalismo, Realismo, Simbolismo, Impressionismo, Expressionismo: "Ao libertar a personalidade criadora do artista, o Romantismo legou-nos este princípio de linguagem que não pertence a nenhuma escola, a nenhuma estética coletiva e apenas possui valor em virtude de sua singularidade".

\subsubsection{Hungria}

Béla Bartók nutre sua linguagem musical com elementos vivos, resultado de uma minuciosa pesquisa de canções feita na Hungria e posteriormente na Romênia, Ucrânia, Bulgária, Argélia, Egito e Anatólia, realizada com Kodály.

Em 1931 escreve a um amigo: "Minha idéia central (...) é a da fraternidade dos povos (...). Esta é a idéia a que, na medida de minhas forças, procuro servir com o que crio. Por isso não me recuso a nenhuma influência, seja ela de fonte eslovaca, romena, árabe ou qual for, contanto que pura, fresca e sã.. ${ }^{51}$

Os seis volumes do Mikrokosmos, pequenas peças para piano escritas entre 1932 e 1939 para o estudo de seu filho Peter, representam o resultado das pesquisas do compositor, consistindo em um verdadeiro manual didático de todos os "modos" por ele encontrados.

\subsubsection{Brasil}

\footnotetext{
${ }^{50}$ STEHMAN, Jacques. História da Música Européia. São Paulo, Difusão Européia do Livro, 1964, p. 241.

51 Apud MASSIN, Jean \& Brigitte. História da Música Ocidental. Rio de Janeiro, Nova Fronteira, 1997, p. 965.
} 
A não-aceitação dos modelos europeus, seguidos até o início do século XX, a ênfase dada ao tema da nação e a preocupação com a realidade brasileira em debates culturais e estéticos, proporcionaram o surgimento de uma corrente nacionalista com estética fundamentada nas idéias de Mário de Andrade, que perdurou até 1940. Mas há prenúncios de uma busca consciente do sentimento nacional na música erudita a partir da segunda metade do século XIX, realizada por compositores como Brazílio Itiberê e Alberto Nepomuceno, seguidos por Alexandre Levy, Francisco Braga. E se Villa-Lobos pode ser considerado o primeiro representante da modernidade, outros como Camargo Guarnieri, Francisco Mignone e Cláudio Santoro souberam se utilizar de elementos musicais do Nacionalismo.

Dentro da vasta produção musical de Villa-lobos, o repertório pianístico é extenso. Embora existam obras de grandes dimensões, como o Rudepoema, é a peça curta, muitas vezes reunida em coletâneas, a forma escolhida pelo compositor para exteriorizar sua arte.

Para Villa-Lobos, a forma é a "conseqüência da necessidade de repouso relativo da imaginação, mas jamais a repartição simétrica das deduções clássicas" ${ }^{52}$ Portanto, o conteúdo criativo, resultado da pesquisa do rico material folclórico, extrapola, em suas obras, o conceito de forma.

A preocupação com o ritmo, fio condutor de suas obras, capaz de conferir ao tema folclórico um caráter pessoal, pode ser considerado sob um ponto de vista mais amplo, quando o compositor fala da música como elemento universal, gerador de paz através de uma única pulsação: "O coração é o metrônomo da vida (...). Por que

\footnotetext{
${ }^{52}$ Apud HORTA, Luís Paulo. Villa-Lobos - uma introdução. Rio de Janeiro, Jorge Zahar, 1987, p.52.
} 
se desentendem, vivem descompassados raças e povos? Porque não se lembram do metrônomo que guardam no peito, o coração". 53

Villa-Lobos recolheu temas e canções populares já na primeira viagem feita ao Nordeste, entusiasmando-se com a música dos cantadores e seus instrumentos primitivos, com os desafios, com as danças e representações de autos.

Parte do rico material folclórico por ele pesquisado ao longo de suas viagens é encontrado nos onze volumes do Guia Prático, contendo sessenta pequenas peças com temas harmonizados e ambientados, entre elas $\mathrm{Na}$ corda da viola, $\mathrm{A}$ maré encheu, Samba-lelê.

O folclore é considerado por Villa-Lobos o elemento de união entre a manifestação "espontânea" popular e a criação musical elaborada, "intelectual”. Arte que, extraída do povo, a ele retorna após ser burilada na alma do compositor. ${ }^{54}$

\footnotetext{
${ }^{53}$ Apud MACHADO, Maria Célia. H. Villa-Lobos. Rio de Janeiro, UFRJ, 1987, p. 82.

${ }^{54}$ Ibidem, p. 94-95.
} 


\section{Capítulo 3: Macchiette op. 2 de Henrique Oswald: Típica}

\section{Coletânea Romântica}

\subsection{Autor}

Henrique Oswald nasceu no Rio de Janeiro, em 14 de abril de 1852, mudando-se com a família, em 1853, para São Paulo, onde sua mãe se dedicou ao ensino musical e seu pai, ao comércio de pianos, após várias viagens de negócios.

Iniciou os estudos de piano com Maria Carlota, sua mãe, e mais tarde com Gabriel Giraudon.

Aos 16 anos, fixou-se em Florença, onde estudou com Giuseppe Buonamici, através do qual conheceu vários músicos importantes da época, entre eles Liszt e Brahms.

Em 1879, recebeu de D. Pedro II ajuda financeira, através de uma bolsa de estudos na Europa, concessão que perdurou até o início da república e que o reaproximou de sua Pátria.

Esteve no Brasil várias vezes interpretando obras de sua autoria, de estilo romântico, mas apresentando características das escolas alemã, francesa e italiana.

Em 1900 foi nomeado vice-cônsul do Brasil em Havre (França) e, no ano seguinte, em Florença.

Venceu importante concurso de composição promovido pelo jornal Le Figaro de Paris, em 1902, com a peça para piano /l Neige!, escolhida por Saint-Saëns, Gabriel Fauré e Louis Diémer. Assumiu a direção do Instituto Nacional de Música em 1903, no Rio de Janeiro, demitindo-se após três anos, por motivos ligados à intensa 
burocracia existente na Instituição. Fixou-se definitivamente no Rio de Janeiro em 1911, exercendo grande influência no meio musical não só pela atividade didática, como pelo convívio com compositores, intérpretes e críticos, que faziam de sua residência um ponto de encontro.

Quanto ao não-engajamento de Henrique Oswald às novas correntes estéticas, é possível citar, entre outros fatores, o longo período por ele vivido fora do Brasil, seu temperamento e a idade de 70 anos, quando da Semana de Arte Moderna, o que resultou na ausência de defasagem em relação ao que se produzia na Europa, na época.

Lecionou até o fim de sua vida, em 1931, formando pianistas de renome e compositores como Luciano Gallet, J. Otaviano, Frutuoso Viana e Lorenzo Fernandez.

A obra de Henrique Oswald, da qual grande parte foi escrita quando residia em Florença, é bastante extensa, abrangendo quase todos os gêneros. Destacam-se sua música de câmara, como os dois Quartetos com piano, Quartetos para cordas, Quinteto para piano e quarteto de cordas, Trios para piano, violino e violoncelo, Concertos para piano e orquestra, Concerto para violino e orquestra, Sinfonias e grande número de peças curtas para piano.

Suas últimas obras foram dedicadas à música sacra, compondo Missas e prelúdios e fugas para órgão.

\section{2 Obra pianística: predomínio da peça curta}


Henrique Oswald elegeu o piano para seu instrumento desde criança. Sua mãe o iniciou nos estudos, e os diferentes pianos à venda, na loja de seu pai, proporcionaram-Ihe um fascínio especial. Confidente nas peças curtas, o instrumento escolhido seria presença constante nas obras camerísticas.

Seu repertório pianístico é vasto, com predomínio da peça curta, aceita amplamente pelas diferentes camadas sociais e preferida entre os editores. Freqüente entre as obras dos compositores da época, a pequena peça atenderia aos objetivos financeiros e a interesses didáticos, consistindo em repertório alternativo com diferentes graus de dificuldade para o grande número de alunos que orientava, além de consistir em verdadeiro laboratório de regras composicionais.

A partir da década de 1870, Henrique Oswald iniciou a composição de pequenas peças para piano, que mais tarde seriam reunidas formando coletâneas. Formas livres e danças como a mazurca, valsa e tarantela unem-se a minuetos e gavotas, com a preocupação única de manter a alternância entre peças rápidas e lentas.

Segundo José Eduardo Martins ${ }^{55}$, a identidade de um autor é revelada por seu estilo, pois na trama da textura musical de sua obra, são encontradas características que Ihe são próprias. Para Faiga Ostrower, o estilo é a "essência de uma pessoa, sua integração, sua própria coerência interior. Dentro de um estilo o indivíduo desenvolve sua personalidade, se estrutura e estrutura sua obra". ${ }^{56}$

Na música, o estilo envolve não só as características próprias do compositor, mas também da época e da corrente estética do momento. O estilo de uma determinada época resulta da soma de estilos individuais, efetivamente marcados por compositores que se destacaram em seu tempo.

\footnotetext{
${ }^{55}$ MARTINS, José Eduardo. Henrique Oswald músico de uma saga romântica. São Paulo, EDUSP, 1995, p.161.

${ }^{56}$ OSTROWER, Faiga. Criatividade e processos de criação. Rio de Janeiro, Vozes, 2004. p.141.
} 
Em Henrique Oswald, embora sob a influência de compositores contemporâneos europeus, é possível observar tendência ao melodismo e à fluência italiana, preocupação formal, praticada na Alemanha, e a sobriedade, refinamento e elegância, que se enquadram na "clareza francesa", que sobremaneira, a partir do século XIX, incluía também o modo de tocar.

Quanto à trama da textura musical, observa-se uma tendência à percepção horizontal, em detrimento da verticalização.

José Eduardo Martins refere-se à "plasticidade caminhante", um dos atributos da produção de Henrique Oswald, sendo a harmonia decorrente do forte pensamento ondulante horizontal. ${ }^{57}$

A utilização freqüente de arpejos, acordes quebrados e mãos alternadas em movimentos rápidos, que muitas vezes estão relacionados à afinidade com as mãos do compositor, resulta em leveza e constante fluir.

Alfredo Bosi menciona a "infinitude romântica" presente no mundo onírico das barcarolas e berceuses, tema constante na produção de Henrique Oswald, onde "tudo flui, nada se fixa, fim e começo coabitam e se mesclam". ${ }^{5}$

Portanto, arpejos, acordes quebrados, contratempo, síncopa podem ser considerados extensões do ondular constante existente no intimismo de Henrique Oswald.

Também danças com pulsação característica, motivos abstratos e títulos descritivos fazem parte de sua produção pianística.

\footnotetext{
${ }^{57}$ MARTINS, José Eduardo. Henrique Oswald: Compositor Romântico. Tese de Doutorado. São Paulo, FFLCH-USP, 1988, v.2, p.339.

${ }^{58}$ Apud MARTINS, J.E.. Henrique Oswald músico de uma saga romântica. São Paulo, EDUSP, 1995, p.13.
} 
O idioma francês, de mais fácil divulgação, é escolhido para os títulos das peças descritivas, embora o italiano também tenha sido utilizado, como ocorreu com as peças da coletânea Macchiette op. 2.

Esteticamente, a obra de Henrique Oswald identifica-se com correntes francesas do início do século $X X$, pois resultam em produções quantitativa e qualitativamente superiores à italiana. São fatores que influenciaram a opção pelo modelo francês: sua personalidade requintada; atividade diplomática em Havre; premiação de /l Neige!, em Paris.

Quanto à estrutura, há flexibilidade entre as diferentes seções, pois as intenções da forma são direcionadas pela idéia musical:

- seções A e B: podem ter um tema ou dois;

- reexposição de A: pode ser reduzida;

- temas A e B: podem ser contrastantes ou não; podem conter nuances de contrastes.

A ausência de contraste entre A e B resulta numa "impressão monolítica" enfatizando o "horizontalismo caminhante", como afirma José Eduardo Martins. ${ }^{59}$

A obra de Henrique Oswald enquadra-se perfeitamente nos conceitos do Romantismo, apresentando sensibilidade melódica e expressividade, o que favorece a manifestação dos aspectos emocionais. Nela se destacam elegância, sobriedade, distinção.

\footnotetext{
${ }^{59}$ MARTINS, José Eduardo. Henrique Oswald: Compositor Romântico. Tese de Doutorado. São Paulo, FFLCH-USP, 1988, v. 2, p. 297.
} 


\subsection{Peça descritiva: "pintura musical"}

Segundo José Eduardo Martins ${ }^{60}$, há na obra de Henrique Oswald um "amalgamar-se da descrição, sugestão e do elemento programático e cenas vistas ou imaginárias, sensações, sonhos e desejos fazem parte dos títulos de suas obras". Há peças nas quais ocorre uma ação, como em La Caccia (Maccchiette op.2); em ${ }^{60}$ MARTINS, José Eduardo. Henrique Oswald Músico de uma saga romântica, op. cit., p.187. 
outras, o elemento descritivo, inconsciente ou não, nasce da ondulação da água ou balanço calmo, temas também recorrentes em seus desenhos.

A peça curta condensa e favorece os elementos descritivos e pequeninos quadros vão surgindo. É importante considerar o que os desenhos de Henrique Oswald revelam de sua percepção ótica para compreender o descritivo, ou seja, de que forma favorecem a captação do visual, que se transformará em criação sonorodescritiva.

Para Faiga Ostrower, "a imaginação pictórica consiste em ordenar, ou preordenar mentalmente certas possibilidades visuais de concordâncias ou de dissonâncias entre cores, de seqüências ou contrastes entre linhas, formas, cores, volumes, espaços visuais com ritmos e proporções. (...) Cada detalhe, como pintura, faria parte de todo um conjunto imaginado de cores, de tessituras, de acentuações e ritmos visuais". 61

Portanto, os elementos utilizados pelo pintor são análogos aos da linguagem musical, como propõe Eduard Hanslick, “(...) entre o movimento no espaço e no tempo, entre a cor, a delicadeza e a grandeza de um objeto e altura, o timbre e a intensidade de um som impera uma analogia bem fundada", sendo possível "pintarse musicalmente um objeto". 62 O autor salienta ainda o aspecto dinâmico da música em oposição às outras artes, que são estáticas, e observa que "a música acrescenta aos substantivos plásticos estáticos o verbo, a atividade, a agitação interna, descrevendo de forma criativa os estados de ânimo". ${ }^{63}$

É possível que a referida "clareza francesa" e a dinâmica não demasiado contrastante de Henrique Oswald também resultem, respectivamente, da preferência

\footnotetext{
${ }^{61}$ OSTROWER, Fayga. Criatividade e processos de criação. Rio de Janeiro, Vozes, 2004, p.35.

${ }^{62}$ HANSLICK, Eduard. Do Belo Musical. Lisboa, Edições 70, 2002, p.33.

${ }^{63}$ Ibidem, p. 99.
} 
por "linhas exatas" e "tons suaves", proporcionando leveza, fluidez, horizontalidade e a "plasticidade caminhante" de suas obras. 
música e nos desenhos de Henrique Oswald

A imagem do pequeno barco - miniatura, na realidade - apreende o conteúdo essencial da rítmica específica da ondulação e presente nas berceuses, barcarolas e noturnos do autor.

\subsection{Repertório pianístico publicado}

Além de Trois Études, Estudo (Edição Póstuma), Étude pour la main gauche, Scherzo - Étude e Variações sobre um tema de Barrozo Netto, foram publicadas as seguintes peças:

- Polka, op. 1.

- Macchiette, op. 2 - doze peças divididas em quatro fascículos: La Campane della Sera, Scherzo, Valzer, Canzonetta, Ninna-nanna, Marcia, Romanza, Seconda Gavotta, Pastorale, Minuetto, Sarabanda, La Caccia.

- Fogli d'Albium, op. 3: Prélude, Sognando, Impromptu, In Hamac, Romanza, Scherzo.

- Six Morceaux op. 4: Valse, Rêverie, Menue, Berceuse, Barcarola, Impromptu.

- Deux Nocturnes, op. 6.

- Trois Romances, op.7.

- Trois Morceaux, op 8: Valse, Polonaise, Tarantelle.

- Deux Valses Caprice, op. 11.

- Quatre Morceaux, op.12: Sérénade, Valse Impromptu, Berceuse, Tarantelle. 
- Seis peças para piano, op. 14: Berceuse, Mazurka, Tarantella, Barcarola, Noturno, Scherzo.

- Sept Miniatures, op. 16: Confidencia, Mazurka, Travessa, Ingenuidade, Doce Aflição, Saudade, Capricho.

- Impromptu op. 19.

- Feuilles d'Album op. 20: Inquietude, Chansonette, Feux Follets, Désir Ardent.

- Trois Morceaux, op. 23: Menuet, Romance, Valse.

- Deux Valses, op. 25.

- Album, op. 32: Romance, Valse, Sérènade, Menuet.

- Album op. 33: Sur la Plage, Idyle, Pierrot.

- Polonaise, op. 34.

- Album, op. 36: Bébé s'endort, Pierrot se Meurt, Chauve-Souris.

- Edição Escolar: Pequena Marcha, Valsa, 1 Marcha, 2 Marcha, Gavotta, Triste, Chansonette, Folha d' Album, Valsa Lenta, Mazurka, Tarantella, Scherzando.

- Un Rêve.

- En Nacelle.

- Sérénade Grise.

- Sérénade.

- Serenatella.

- II Neige!.

- Valsa Lenta. 


\subsection{Macchiette op.2}

O conceito de Daniel Lesur sobre a suíte (já mencionado no capítulo 1), considerando-a uma imagem da vida, por nascer de atividades espontâneas como a dança e a canção, aplica-se à coletânea Macchiette op.2 (miniatura, esboço pictórico ou não), onde diferentes danças e canções convivem com cenas da vida: os sinos do campanário ao entardecer, a valsa lenta, a marcha vibrante, uma caçada, a canção suave que embala o berço e outras.

Dividida em quatro fascículos, totalizando doze peças compostas no final da década de 1870 e início da década de 80, a coletânea foi editada por G. Venturini, Florença, e apresenta a seguinte titulação italiana:

Fascículo 1: La Campane della Sera

Scherzo

Valzer

Fascículo 2: Canzonetta

Ninna-nanna

Marcia

Fascículo 3: Romanza 
Seconda Gavotta

Pastorale

Fascículo 4: Minuetto

Sarabanda

La Caccia

\subsubsection{Le Campane della Sera}

Composta na tonalidade de Ré Maior, uma das mais freqüentes na obra de Henrique Oswald, esta peça de apenas vinte compassos inicia a coletânea e consiste na descrição cadenciada e monótona do som de sinos ao entardecer:

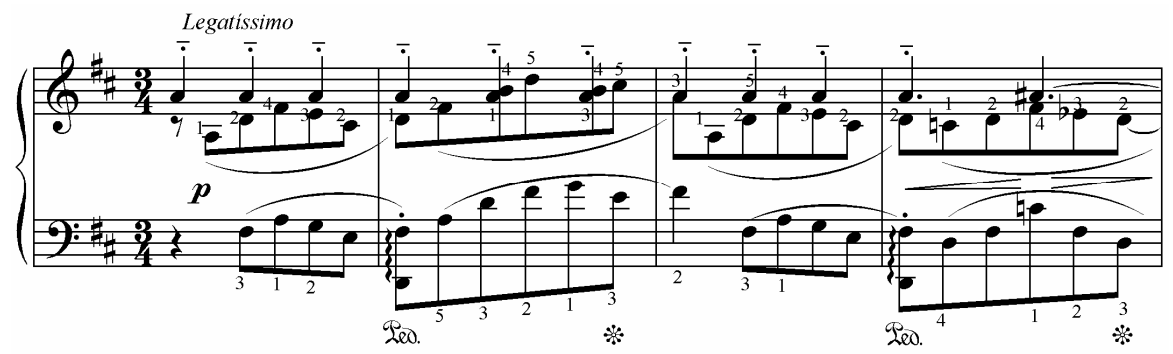

A linha melódica é apoiada por um acompanhamento também homogêneo ritmicamente, evitando contrastes na textura, mas extremamente ondulante, como a conduzir as vibrações da nota lá, sempre presente.

Apenas os compassos 8 e 9 apresentam a nota repetida uma oitava acima. A reexposição prossegue como no início até a coda, onde a nota lá, acompanhada de um rallentando, parece soar infinitamente em oitavas cada vez mais agudas. 
É interessante comparar o descritivo linear dos sinos, em Henrique Oswald, com a atmosfera introspectiva obtida por Alexander Borodine, em Au Couvent ( Petite Suite):

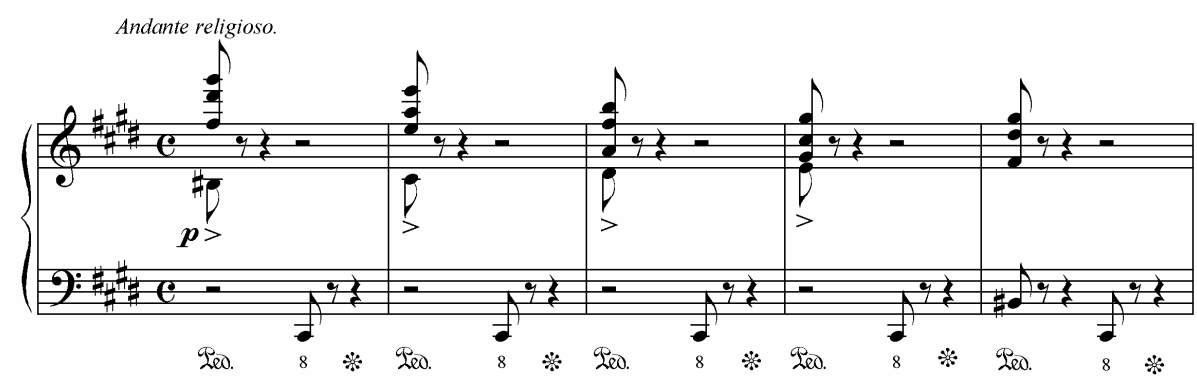

Ou ainda a alegria dos sinos em Son de cloches, (Morceaux lyriques ), de Grieg, que dobram com timbres diferentes e simulam movimentação através de uma sucessão de quintas:

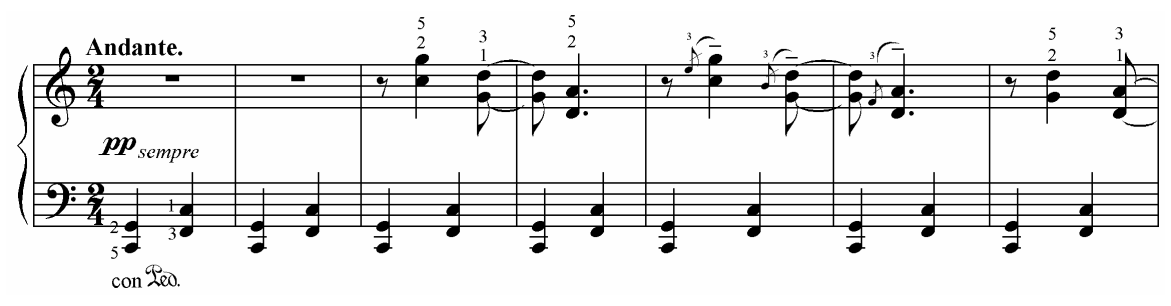

Além de indicar o transcorrer do tempo, os $\operatorname{sinos}^{64}$ sempre anunciam, participam, convidam à introspecção. Analogamente, a peça Le Campane della Sera, que inicia a coletânea, conclama para uma seqüência de miniaturas: pequenos quadros contendo cenas da vida.

${ }_{64}$ Assim como ocorre na música a visualização do campanário através das badaladas, o tema é propício, na literatura, para recriar o universo sonoro, como mostra o "Poema" de Fernando Pessoa:

Ó sino da minha aldeia, Dolente na tarde calma, Cada tua badalada

Soa dentro da minha alma.

A cada pancada tua, Vibrante no céu aberto, Sinto mais longe o passado, Sinto a saudade mais perto. 


\subsubsection{Scherzo}

Inicialmente era uma composição breve, apresentando movimento rápido e acentuações rítmicas.

Beethoven consolida sua presença em sonatas, sinfonias e obras de câmara, em substituição ao minueto, prática que já ocorrera em quartetos tardios de Haydn.

Sua forma ternária difere da pequena forma do minueto pelo caráter não dançante, pelo ritmo e movimento mais vivos e por apresentar, na parte central, maior diversidade de modulações e temas.

No período romântico, o scherzo não só perdeu aos poucos o caráter espirituoso, passando a apresentar certa dramaticidade, como teve suas dimensões ampliadas. Os quatro scherzos para piano de Chopin contribuíram para a afirmação dessas composições como movimento independente, no caso, peças de concerto.

O Scherzo op. 2 no 2, em Si Menor, de Henrique Oswald, apresenta alternância contínua entre as mãos sempre em semicolcheias, excetuando-se os três últimos compassos. Produzindo o efeito de um "perpetuum mobile", é escrito em 
um único pentagrama imitando a escrita violinística, seguindo a tradição de Paganini, apreendida por Liszt.

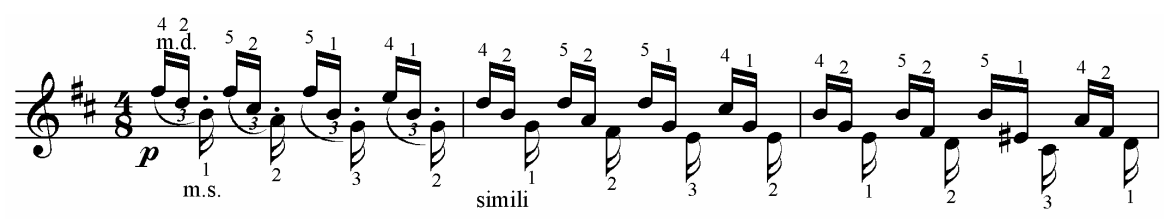

$\mathrm{Na}$ forma ABA seguido por uma coda, apresenta apenas contrastes harmônicos em B, produzindo características espanholas resultantes do emprego da cadência frígia.

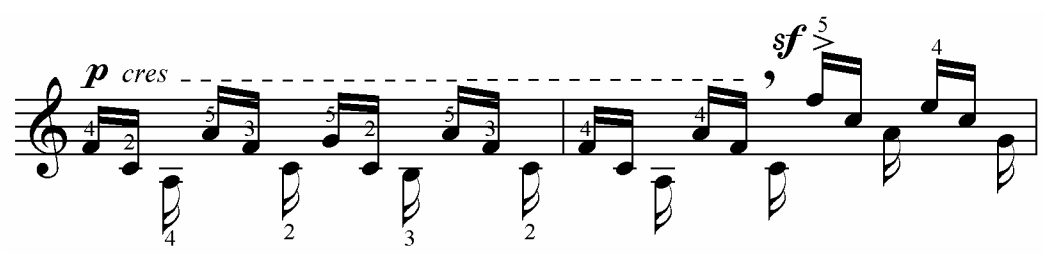




\section{5. 3 Valzer}

Dança de caráter popular e grande prestígio no século XIX, provocou o abandono de quase todas as outras danças. Generalizou-se após a Revolução Francesa, atingindo todas as classes sociais.

De provável origem alemã (waltzen equivalente ao latim volvere = girar sobre si mesmo), o termo surgiu por volta de 1765-70, referindo-se a composições semelhantes ao ländler austríaco e às antigas danças alemãs de três tempos, dissociado ainda do sentido de "dança giratória".

Peças simples, alegres, com características especificamente alemãs, foram escritas por Mozart, Beethoven, Schubert e, mais tarde, Brahms.

Embora de caráter variável, podendo ser lenta ou mais animada, a valsa tornou-se, com o tempo, principalmente em Viena, mais flexível, rodopiante, com o primeiro de seus três tempos bem marcado, atingindo o apogeu com os filhos de Strauss, Johann e Josef. Valsas nos mais diversos estilos foram compostas por quase todos os compositores românticos e pós-românticos, sendo encontrada em obras sinfônicas (Berlioz, Mahler), em ballets (Thaikovsky, Delibes) e óperas (Fausto de Gounod).

Entre as coletâneas de valsas do período, destacam-se as de Chopin. 
A valsa aparece com freqüência entre as danças escritas por Henrique Oswald. Não a rodopiante, tipicamente vienense, mas a propícia ao salão, de andamento confortável, com características melódicas e temas geralmente contrastantes. Exceção à Valsa op. 11 oํ 1, na qual Henrique Oswald obtém resultados absolutamente de grande impacto e comunicabilidade.

Escrita na forma ABA, a Valzer op. 2 no 3 apresenta o tema sincopado em toda a sua extensão. De andamento lento, cadenciado, possui B não contrastante, mas com andamento mais animado.

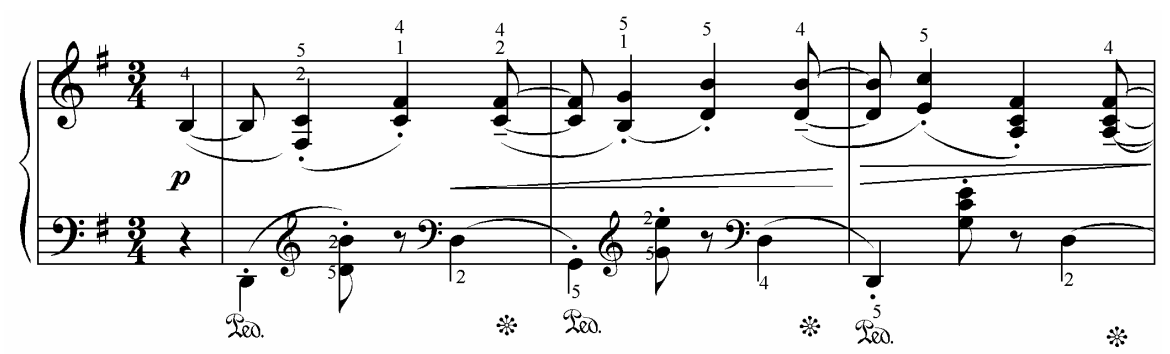




\subsubsection{Canzonetta}

A canzone instrumental ou canzone da sonar consiste na transcrição para órgão de peças vocais, especialmente canções polifônicas francesas, tendo origem no século XVI, na Itália.

Peças originais foram compostas para a suíte pelos Gabrieli, no século XVI e Frescobaldi, no século XVII, que procuraram adaptar o estilo vocal ao instrumento utilizado.

A sonata se origina, em parte, da canzone da sonar.

Com B não contrastante, a canzonetta op. 2 nำ 4 de Henrique Oswald apresenta, no acompanhamento, o si bemol sincopado funcionando como nota pedal e reforçando a fundamental, por quase toda a extensão. Intercalado ao tema e com a indicação dinâmica " $p$ " quase constante, o contratempo proporciona, na peça, uma atmosfera etérea.

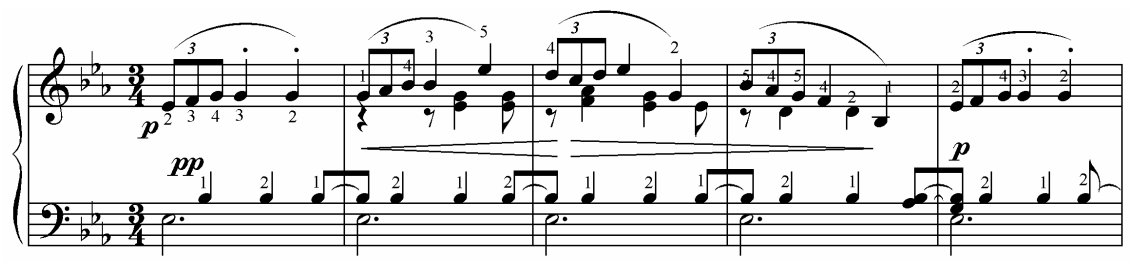


Segundo José Eduardo Martins ${ }^{65}$, em manuscrito com data de 25 de junho de 1878, essa peça está preliminarmente na tonalidade de Mi Maior e tem o título de Romance sans paroles.

\subsubsection{Ninna-Nanna}

Com as denominações de nanna, ninnaretta, nonna, nonna pastorale, nonna in pastorale, consiste em uma categoria de Pastoral de Natal vocal, contendo canções de ninar ao Menino Jesus, cultivadas na Itália pelo menos desde o século XVII. O termo, nesse sentido, é sinônimo de Pastoral e canções com essas características são encontradas nos séculos XVIII e XIX por vários compositores, incluindo Francesco Durante e Giovanni Paisiello.

Peça descritiva, Ninna-Nanna op. 2 no 5 de Henrique Oswald apresenta um tema de forma velada (o embalo cuidadoso, cadenciado de um berço) e um acompanhamento imutável em toda sua extensão. O conceito de forma ternária é atribuído unicamente a mudanças tonais, pois uma só frase compõe as diferentes seções da obra.

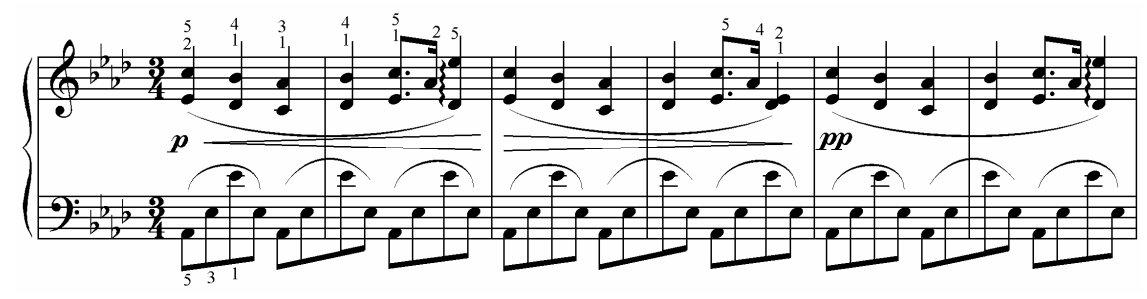

\footnotetext{
${ }^{65}$ MARTINS, José Eduardo. Henrique Oswald músico de uma saga romântica. São Paulo, EDUSP, 1995, p.195.
} 
É interessante notar a articulação do acompanhamento, que parecendo estar escrito em compasso $3 / 2$, proporciona fluidez e leveza à peça, que não apresenta, em seu transcorrer, pontos de tensão.

\subsubsection{Marcia}

A música para marchar consiste na ornamentação de um ritmo constante marcado pelo tambor, com o objetivo de regular o passo de grande quantidade de pessoas.

Em compasso binário ou quaternário, apresenta, com freqüência, a divisão dos tempos em valores desiguais (mais largo o primeiro que o segundo, com 0 objetivo de facilitar a acentuação do passo) e um trio, onde há predomínio da melodia.

A Revolução Francesa e as Guerras Napoleônicas proporcionaram grande impulso à marcha e, no século XIX, muitas delas foram escritas por Schubert, Schumann e Chopin.

As características expressivas diferem de acordo com a finalidade a que se propõe: um brilhante desfile militar, uma solene marcha nupcial ou lento cortejo.

Em compasso binário, a Márcia op. 2 n $6^{\circ}$ de Henrique Oswald é escrita na forma ABA, sendo A subdividida em aba'. 


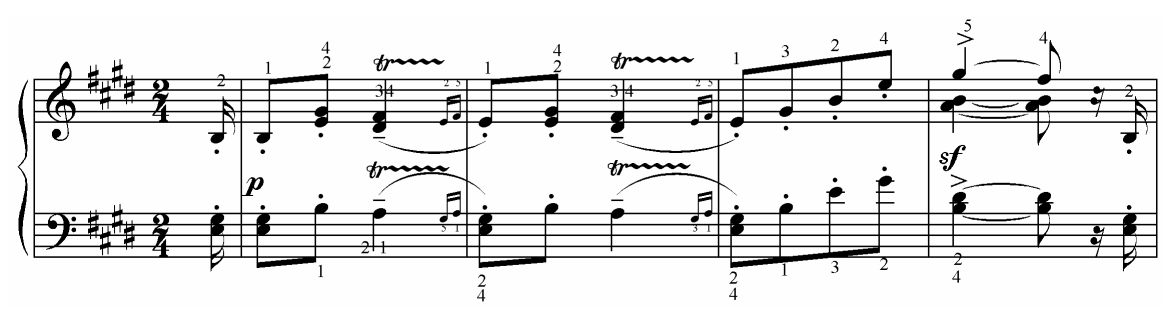

Com a linha melódica no baixo, a seção $B$ é acompanhada à maneira de pizzicatto, em contratempo.

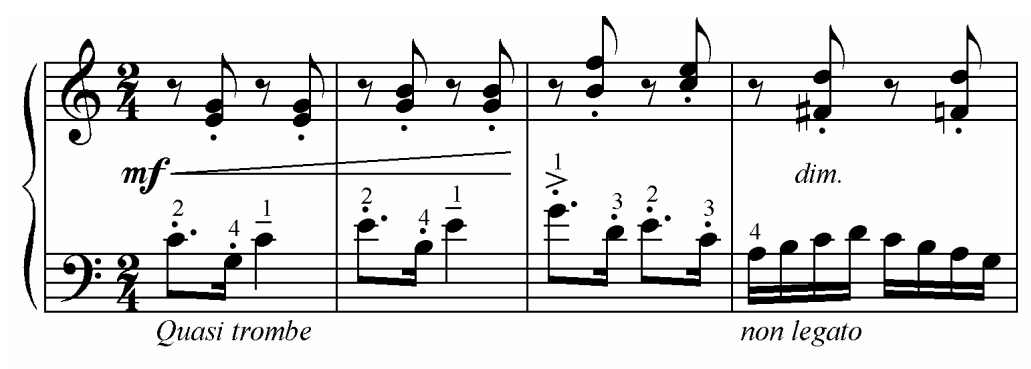




\subsubsection{Romanza}

Canto geralmente sentimental, amoroso, muito cultivado na época préromântica e romântica. Como música instrumental, o termo passou a designar, no século XVIII, uma peça particularmente melodiosa.

A ausência do elemento dramático e o predomínio da melodia na Romanza diferem da Balada, também presente na época. A série de Romances sans paroles para piano, de Mendelssohn, constitui importante exemplo do gênero.

Embora não apresente uma estrutura bem definida, com freqüência segue a do rondo ou a forma lied.

A repetição do tema em ambas as mãos em intervalo de oitava, na Romanza op. 2 ํo 7 de Henrique Oswald, intensifica a linha melódica, caracterizada pela flexibilidade e pela indicação um poco agitato. $\mathrm{O}$ acompanhamento, entremeado à melodia, coincide, em algumas ocasiões, com o próprio tema. 


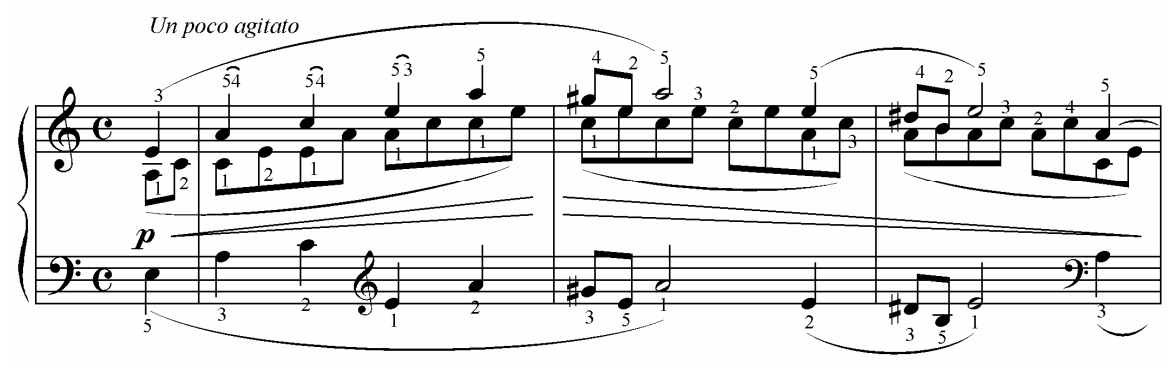

Toda a seção B transcorre com a presença de um pedal em dó alterado cromaticamente no final, preparando o retorno para A.

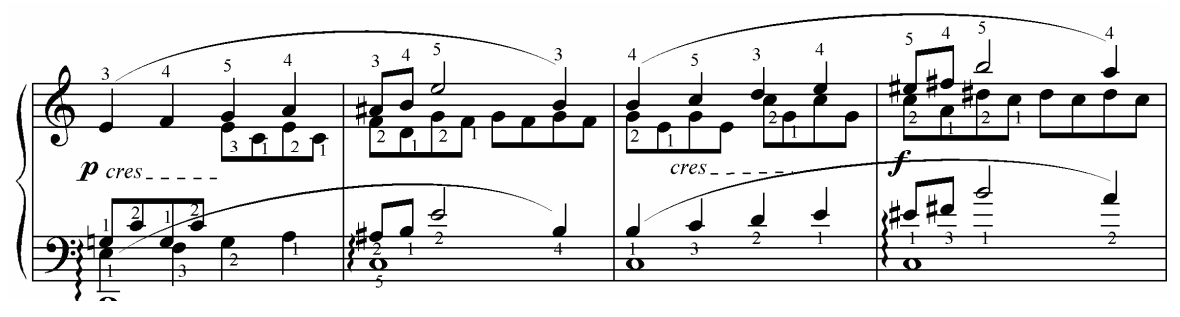




\subsubsection{Gavotta}

Dança cujo nome provém do termo gavots, habitantes da região de Gap, na França, onde ela tem origem. Conhecida desde fins do século XVI, possui ritmo binário, andamento moderado mas alegre e geralmente tem início com anacruse de meio compasso.

Normalmente situa-se depois da Sarabanda, em uma suíte instrumental. Muitas vezes, é seguida por outra gavota representando um trio, como ocorre no minueto. A segunda gavota pode apresentar um bordão sonoro, que lembra uma gaita de foles.

A gavota subsistiu como peça independente, após o período das suítes.

Alternando as nuances dinâmicas e articulações em staccato e legato, a Seconda Gavotte op. 2 n $8^{\circ}$ de Henrique Oswald é marcada por acentuações que Ihe conferem um caráter alegre e apresenta, na mão esquerda, a síncopa funcionando como elemento timbrístico. 


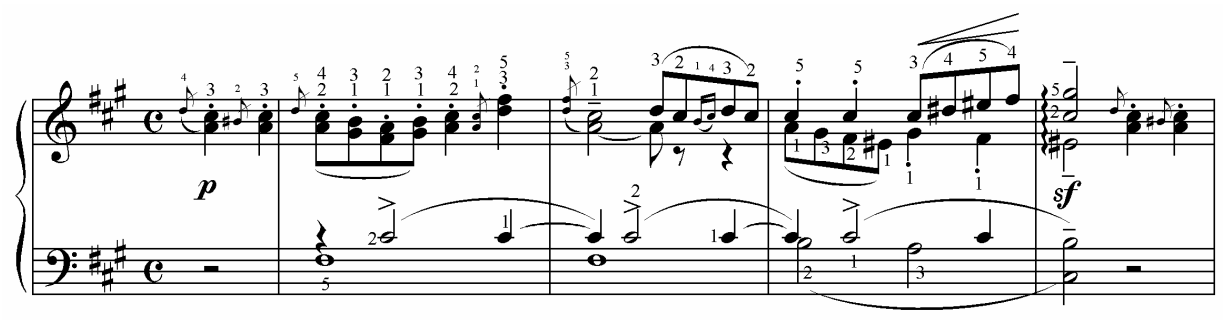

Na forma $A B A$, sendo A composta por aba', a peça traz a recapitulação de $A$ de forma reduzida e a seção intermediária (em Ré Maior) em tonalidade diversa da seção $A$.

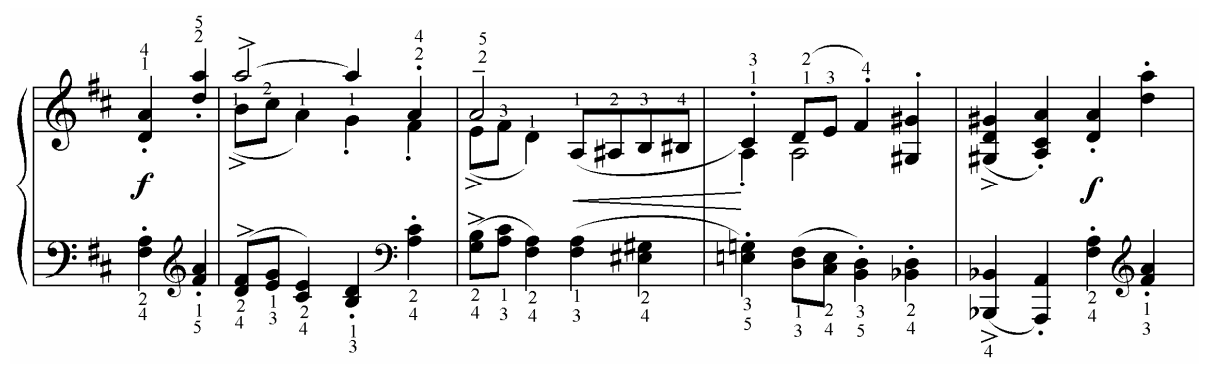




\subsubsection{Pastorale}

O termo Pastoral designa obras instrumentais e teatrais, que descrevem cenas do campo ou expressam sua atmosfera.

Antes do surgimento da ópera, o termo referia-se a pequenas obras cênicas, cujo texto era cantado pelo coro. Logo passou a designar pequenas óperas de caráter bucólico, que mais tarde foram preteridas pelo interesse por temas históricos.

Sob a influências das Arcádias (academias poéticas que cultivavam o gênero bucólico), no final do século XVII, os temas bucólicos, mais uma vez, tornaram-se freqüentes.

Na Itália, constatou-se a presença do termo pastoral na música religiosa, referindo-se à Natividade do Senhor, o "Bom Pastor", no século XVII.

Em compasso $\frac{6}{8}$ e com o tema repetido na oitava como um cânone, a Pastoral op, 2 no 9 de Henrique Oswald cria uma ambientação tranqüila na seção A, em uma atmosfera isenta de tensão, com o tema ecoando apoiado em nota pedal. 


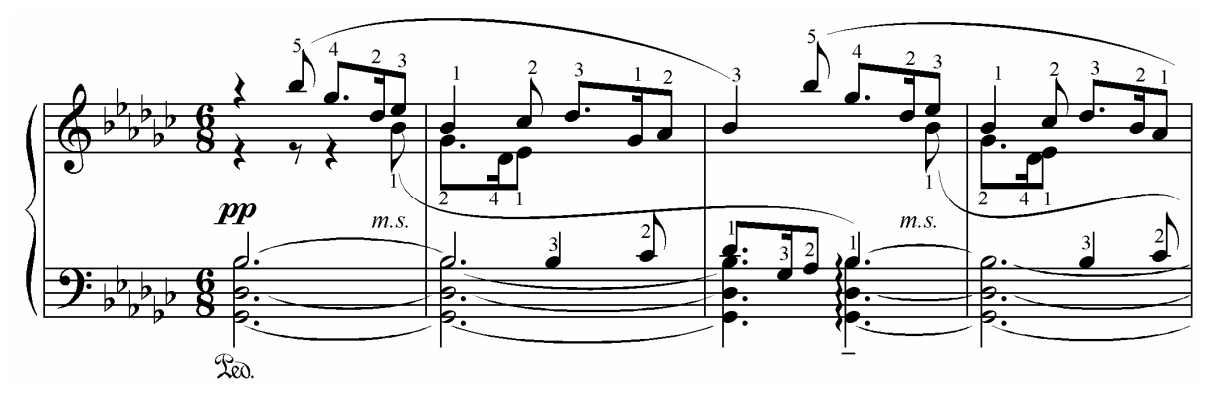

Mais movimentada e precedida de um transição derivada de $A$, a seção $B$, em staccato, apresenta caráter e pulsação diferentes, remetendo à idéia festiva de dança campesina.

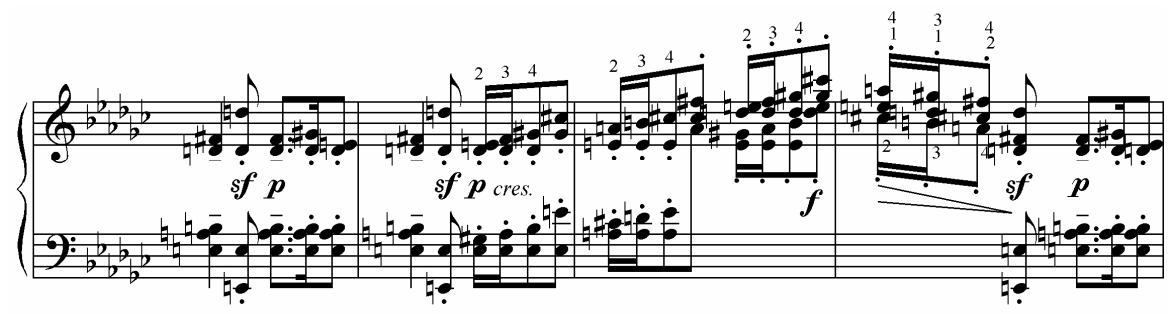




\subsubsection{Minuetto}

Dança francesa muito conhecida na corte de Luís XIV e XV, tornou-se a dança mais popular entre a aristocracia européia.

Em compasso ternário e ritmo lento, tinha por objetivo expressar cumprimento, saudação. Era, em geral, seguido por um segundo minueto, mais melódico, em forma de trio.

Freqüentemente incluído nas suítes barrocas, o minueto teve aos poucos seu andamento acelerado, tornando-se um movimento padrão das Sonatas, Sinfonias e Quartetos de cordas, resultando no scherzo de Beethoven, que o sucede.

Poucos compositores interessaram-se por essa dança no século XIX, mas minuetos foram escritos por Bartók, Schoenberg e Ravel no século XX.

O minuetto op. 2. ํo 10 de Henrique Oswald, de caráter nitidamente barroco e escrita polifônica, não é seguido por um trio: 


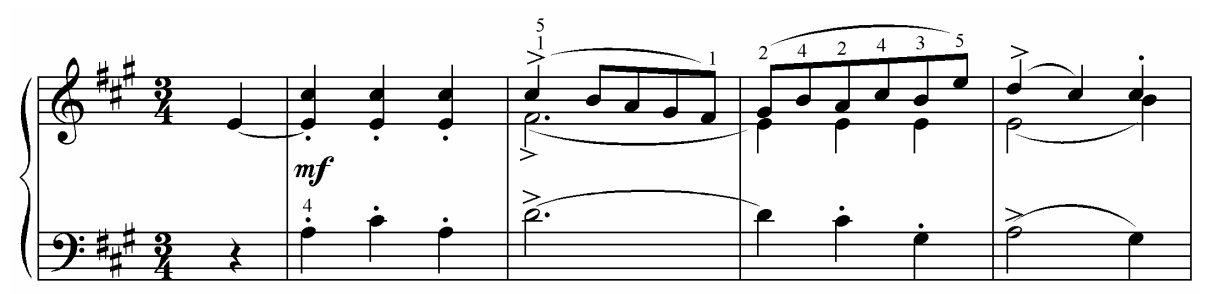

Com o tema no baixo, a seção $B$ apresenta a mesma tonalidade e uma reexposição reduzida encerra o minueto.

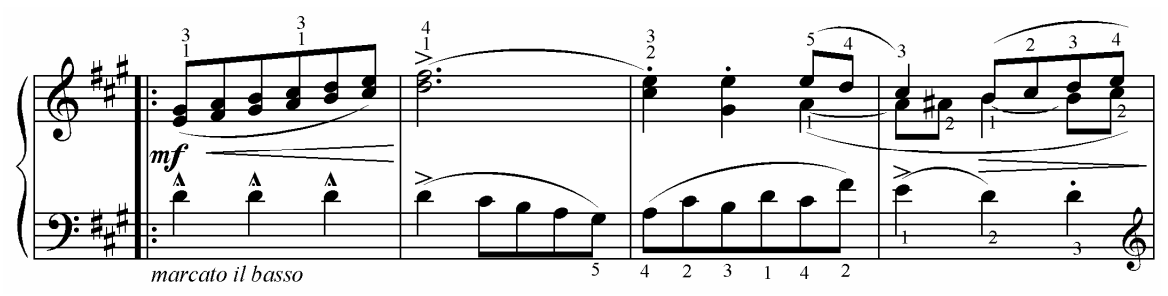




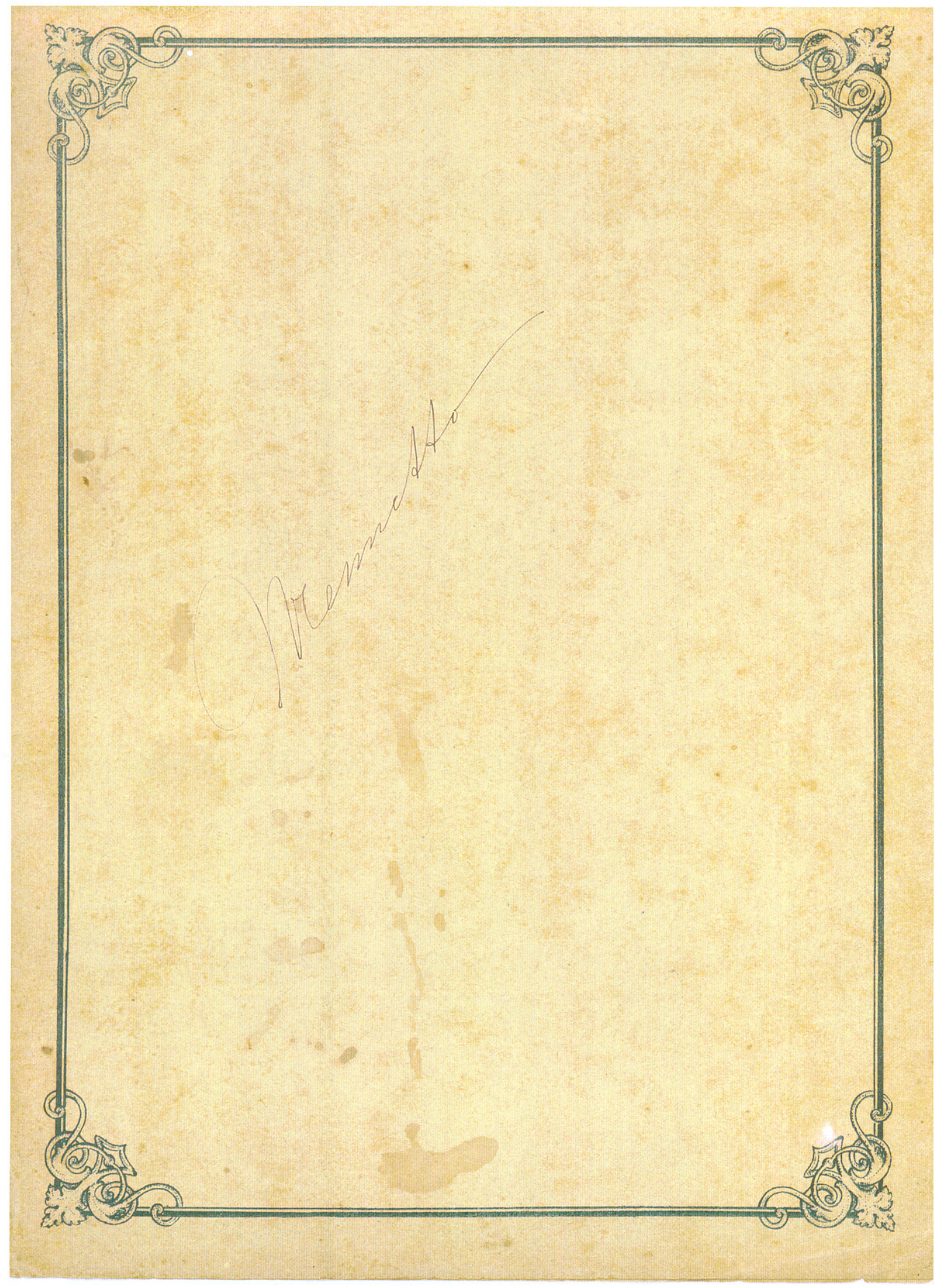

Minuetto dedicado à sua mãe Carlota, no dia de seu aniversário.

(fac- símile do manuscrito autógrafo - coleção particular) 


\section{Q Mialliadre je. Oswald}

MP
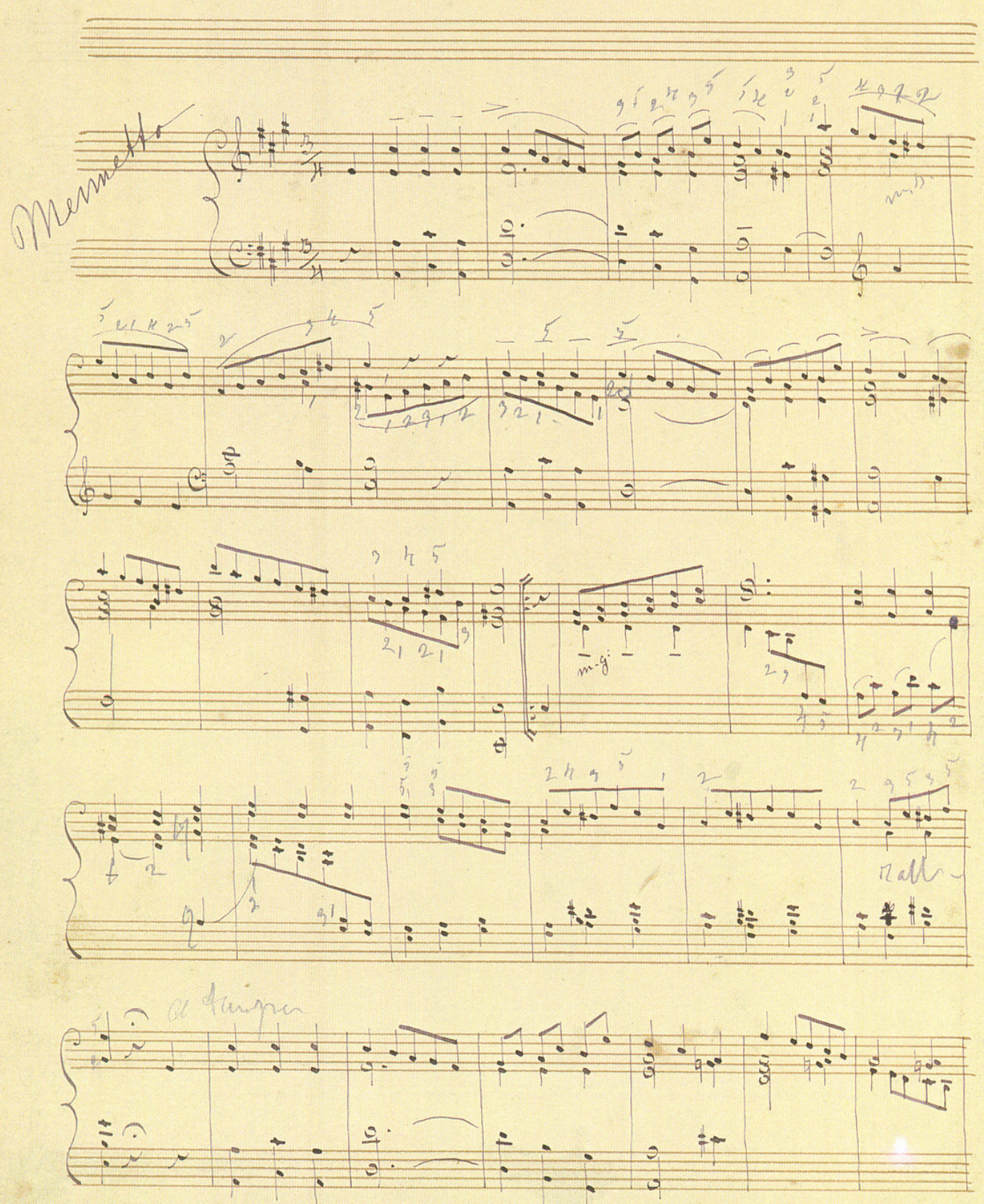


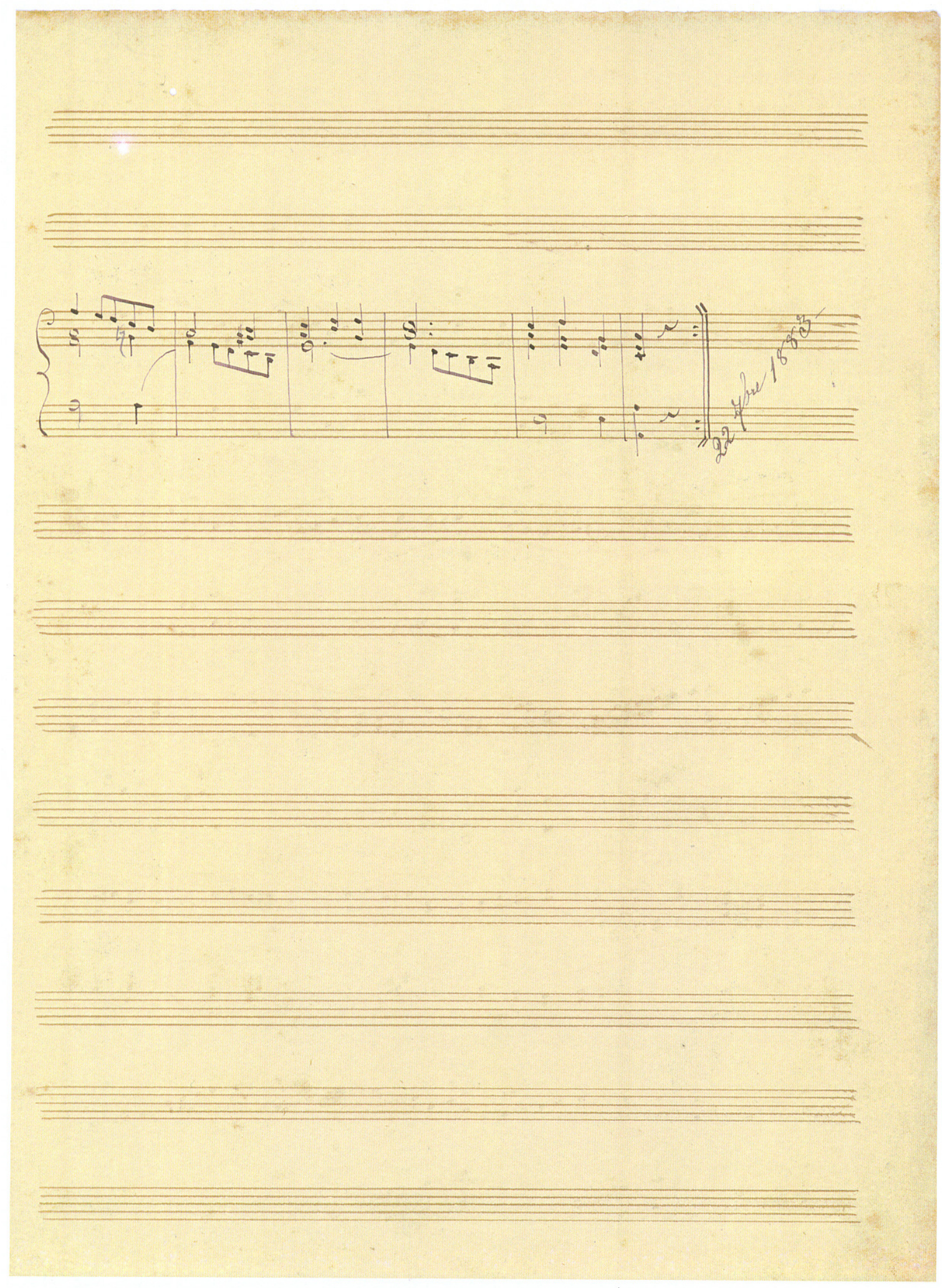




\subsubsection{Sarabanda}

Dança inicialmente cantada, de origem oriental ou espanhola. Surgiu na Espanha, no século XVI, apresentando características lascivas, sendo proibida no final do reinado de Philippe II. ${ }^{66}$

É introduzida na corte da França por volta de 1588, adotando características nobres e transformando-se em uma dança grave, lenta, de melodia expressiva e compasso ternário.

Apreciada em muitos países da Europa e freqüentemente apresentando rica ornamentação, passa a fazer parte, no século XVIII, da suíte clássica, situando-se após a courante. Aparece nas suítes de Louis Couperin, François Couperin, Rameau, Telemann, Haendel, J. S. Bach.

Em 1887, Erik Satie escreveu três Sarabandes para piano, importantes por suas inovações harmônicas. Debussy, em sua suíte Por le piano, também inclui essa dança.

A sarabanda op. 2 no 11 de Henrique Oswald é escrita na forma ABA, apresentando estilo renascentista e escrita polifônica:

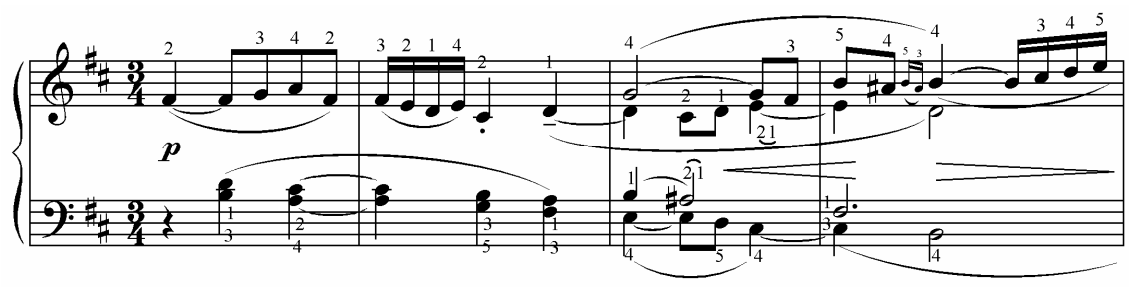

\footnotetext{
${ }^{66}$ Frederick Dorian observa que a lei espanhola, em 1583, instituiu a pena de 200 chicotadas pelo fato de dançar e cantar a sarabanda. Também os homens eram condenados a permanecer seis anos nas galeras, e as mulheres, ao desterro. DORIAN, F. Historia de la Musica através de su ejecucion. Buenos Aires, Editorial Schapire,1950,p.120.
} 
Uma justaposição de acordes interrompe o estilo inicial, na seção $B$, que é seguida pela reexposição, na qual ocorre uma intensificação da polifonia.

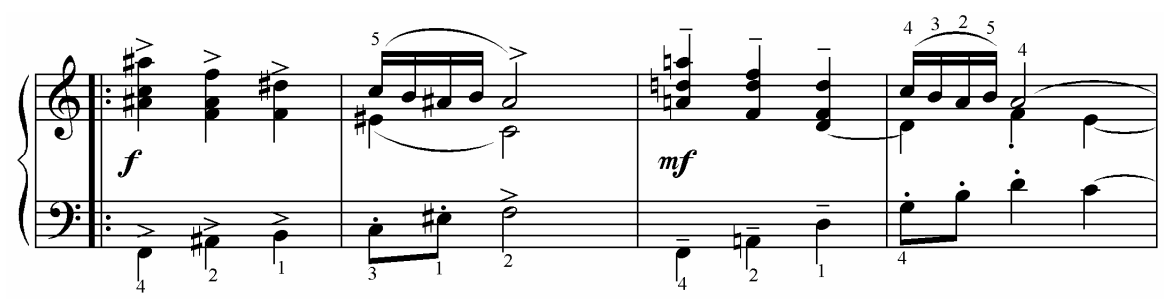




\subsubsection{La Caccia}

Composição vocal muito comum na Itália, no século XIV e início do século $\mathrm{XV}$. Tendo como tema cenas de caça, apresentava duas partes vocais bastante ornamentadas escritas em forma de cânon. Propagou-se em Florença na mesma época que o madrigal.

No século $\mathrm{XVI}$, designava canções polifônicas sobre o mesmo tema, mas elementos descritivos podiam ser encontrados: imitação de cães, cavalos e gritos de caçadores.

Para Charles Rosen ${ }^{67}$, as chamadas de trompa encontradas em obras de Beethoven e Schubert, no século XIX, consistem na evocação romântica da floresta. Opondo-se à simples descrição tonal de pássaros e riachos do período barroco, o som que ecoa distante na paisagem romântica representa a memória, reflexo das novas ambições dos poetas e pintores de paisagens, agora representadas, na música, por harmonias e motivos.

Finalizando a coletânea na tonalidade de Ré Maior, La Caccia op. 2 ํo 12 apresenta, na seção $A$, contrastes dinâmicos formando eco, reproduzindo as chamadas de trompa. A condução das vozes ocorre de forma paralela e o tema, em staccato e marcado por acentuações, confere uma movimentação contínua à obra.

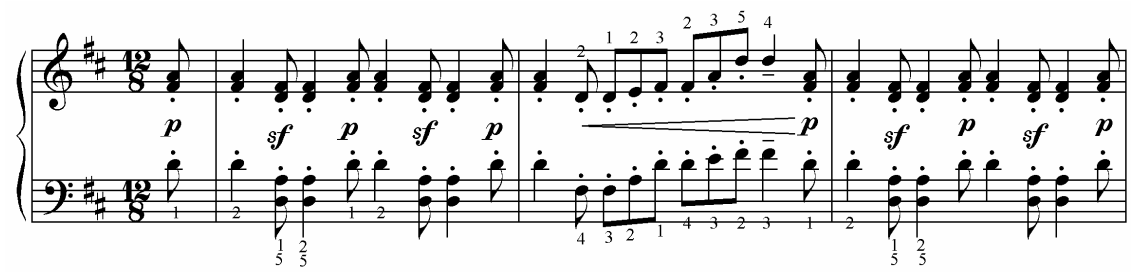

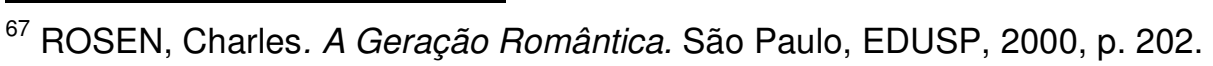


$\mathrm{Na}$ parte central, escrita na tonalidade relativa menor, a mão esquerda apresenta o tema em legato com características melódicas, enquanto a mão direita, sugerindo o tropel dos cavalos, faz acompanhamento em contratempo e staccato.

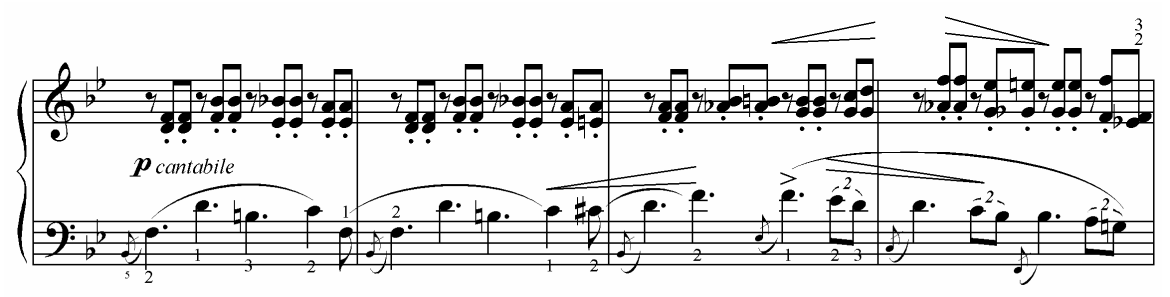

Cada peça da coletânea Macchiette op. 2 revela características composicionais peculiares de Henrique Oswald, fazendo transparecer seu estilo: 
- O "horizontalismo caminhante" está presente em La Campane della Sera, Scherzo, Romanza, La Caccia (seção A);

- A ausência de contraste entre as seções A e B resulta na "impressão monolítica", ratificando a monotonia proposta pelo tema em La Campane della Sera e Ninna-Nanna;

- Além das ondulações próprias da berceuse Ninna-Nanna e do compasso $6 / 8$ da Pastoral, a mesma atmosfera pode ser encontrada na Valzer e na Canzonetta, agora resultantes das síncopas;

- O universo descritivo-musical do compositor passa pelo crivo da percepção ótica, resultando em minuciosa observação e na riqueza de detalhes nas peças $L a$ Campane della Sera, Ninna-Nanna, Pastoral, La Caccia.

Características como preocupação formal, requinte, assim como a demonstração de ter o compositor um profundo conhecimento da harmonia e contraponto, estão presentes ao longo da obra.

Com relação ao início e final da coletânea, é possível observar que:

- ocorre o retorno da tonalidade inicial (Ré maior), uma das mais utilizadas pelo compositor;

- há uma preparação para esse retorno, pois tanto a segunda peça quanto a penúltima estão em Si menor;

- ambas são descritivas;

- há a presença de um elemento sonoro que participa, comunica algo, no contexto descritivo de ambas as peças (sino - proveniente de um único local, o campanário; trompa - cujo som percorre e ecoa pela floresta). 
Portanto, "fim e começo coabitam e se mesclam", sinalizando a presença da "infinitude romântica".

\section{Capítulo 4: Processos Didáticos Através da Pequena}

\section{Forma}




\subsection{A pequena forma e o universo infantil}

Pequenas peças para piano permitem não só abordar problemas técnicos e expressivos de forma gradual, como representam uma oportunidade para se observar e estudar o estilo de um compositor e relacioná-lo com suas demais produções.

Embora exerçam fascínio também entre os adultos, alguns compositores utilizaram pequenas peças com o objetivo de revelar o universo infantil, remetendo a importante aspecto romântico: a nostalgia da origem, ou seja, a valorização da criança e do jovem, enfatizando sua pureza e inocência, por se acharem mais próximos da natureza divina e, portanto, ainda não corrompidos pela sociedade.

Liszt captou de forma sensível a essência das obras referentes ao mundo infantil escritas por Schumann e comenta que "nas Cenas Infantis, no Álbum para a Juventude, nas Peças para Piano destinadas a Grandes e Pequenas Crianças, revela-se aquela graça, aquela ingenuidade que sempre acerta, aquele traço espiritual que faz as crianças nos tocarem de modo tão singular e que, enquanto a sua boa fé nos faz sorrir, nos embaraçam quando fazem perguntas com agudeza de espírito(...)."68

Também conhecidas como Christmas Pieces, as Six Children's Pieces op. 72 de Mendelssohn foram escritas quando o compositor estava na Inglaterra, em 1842.

Apresentando gradativo aumento dos níveis de dificuldade, o Álbum para a Juventude op. 68 de Schumann, escrito em 1848, apresenta não só títulos descritivos, como outros com ambientação característica dos contos de fada. $O$

\footnotetext{
${ }^{68}$ KIEFER, Bruno. "O Romantismo na Música". IN: GUINSBURG, J.O Romantismo. São Paulo, Perpectiva, 1978,p.220.
} 
álbum inteiro foi escrito em dezesseis dias, em um período de descanso após a composição de sua única ópera, Genoveva.

Tchaikovsky também escreveu o seu Álbum para a Juventude op. 39 nas mesmas circunstâncias, após o término da ópera Eugène Onegin, e esboços dessas peças para piano são encontrados muitos anos depois em obras como a Sinfonia em Mi menor (1888), Dó menor (1893) e na suíte Quebra-nozes (1892).

Também é possível conhecer muito das composições de César Franck para orquestra, câmara e piano através das dezoito Petites Pièces. Com exceção da primeira, Les plaintes d'une pupée, e da décima, intitulada Danse lente (escrita em uma forma muito simples de variação no mesmo ano das Variações Sinfônicas), as peças da coleção foram originalmente escritas para harmônio.

Selecionadas entre duas coleções escritas entre 1858 e 1865, e em 1890, ano de seu falecimento, portanto, antes e depois de suas obras maiores, o volume em questão representa uma instrutiva preparação para o estudo das grandes obras do compositor, por conter, de forma condensada, nítidas características de seu estilo.

A suíte Children's Corner de Debussy, escrita entre 1906 e 1908, para sua filha Chouchou com amorosa dedicação, embora apresentando níveis mais elevados de dificuldade, recria no estilo do compositor, todo o espírito do universo infantil.

Muitas outras coletâneas com objetivos didáticos são escritas ao longo do século XX por compositores como Kabalevsky (Vinte e quatro Pequenas Peças), Khatchaturian (Álbum para Crianças), e Shostakovich (Seis Peças para Crianças). 


\subsection{Pequena forma: síntese do processo criativo a beneficiar a didática}

As pequenas peças para piano do período romântico podem ser, de uma maneira geral, divididas em três grupos distintos:

- Títulos Genéricos: Momento Musical, Folha d'album, Prélude, Intermezzo, Humoresque, Romance, Canção sem palavras, Improviso.

Títulos como Prélude e Intermezzo, que em sua origem introduziam uma suíte ou situavam-se entre outros movimentos, transformaram-se em peças interpretadas individualmente ou em grupo. 
- Títulos Descritivos: evocando uma cena ou estado de alma, incluindo Barcarolas e Berceuses.

- Danças: notadamente a valsa, mazurka e inúmeras peças cultivando melodias, ritmos e evocando atmosferas de danças típicas de diferentes nações, como as danças eslavas de Dvorák ou springdans, halling ou gangar de Grieg.

A grande quantidade de música de dança escrita no século XIX foi destinada aos salões da burguesia, para ser dançada ou não, tendo, portanto, como objetivo, a aplicação prática ou apenas a escuta.

Do ponto de vista composicional, é possível deduzir a respeito da pequena forma romântica:

- exemplificam as tendências vigentes no século;

- condensam as características expressivas das obras maiores do compositor, no mesmo período;

- permitem criar, em poucos compassos, a atmosfera pretendida;

- a grande diversidade de caráter permite explorar uma multiplicidade de problemas técnicos e expressivos;

- por não seguirem formas fixas, favorecem a criatividade melódica e harmônica;

- as inflexões de andamento resultantes de rubatos, síncopas e deslocamentos da acentuação, favorecem a descrição de estados emocionais.

Do ponto de vista didático, a pequena forma romântica:

- revela as características de estilo do compositor;

- permite conhecer, de forma abrangente, as tendências da época; 
- as peças de cunho nacionalista proporcionam contato direto com as raízes dos diferentes povos;

- a flexibilidade melódica, afetiva, favorece a expressividade;

- a matéria sonora adquire significação especial explorando o cantabile e desenvolvendo diferentes possibilidades de toque;

- a harmonização, como recurso romântico de originalidade, deixa transparecer características peculiares do compositor;

- possibilita a utilização de diferentes recursos de pedais.

Como já foi comentado, a música romântica requer a valorização das diferentes nuances, obtida pela sensibilidade do intérprete que enfatizará detalhes expressivos e contrastes dinâmicos, com a colaboração do uso dos pedais.

Portanto, o conhecimento da estrutura formal da obra e posterior análise dos elementos harmônicos e melódicos proporciona àquele que estuda e interpreta, contato com as sutilezas da composição e com a subjetividade e estilo de seu criador, que manifestará suas preferências por certas tonalidades, ritmos e texturas características.

Se a música romântica é a voz da sociedade romântica, como o atesta Adolfo Salazar, a pequena forma pianística tem muito a nos dizer: expressão viva da época, representa, na multiplicidade de caráter, estilo e país de origem, a individualidade do compositor, que se faz conhecer na busca incessante por novas cores, sons e sensações, imprimindo em sua obra um caráter extremamente pessoal. 


\section{Conclusão}

Após situar a pequena forma romântica no contexto histórico e cultural do século XIX, procurou-se justificar sua freqüência por parte dos compositores, mesmo em se considerando a presença constante de formas maiores, como a sonata.

Foi possível constatar que a pequena forma se aplica, de maneira mais adequada, aos conceitos estéticos e expressivos da época pelos seguintes motivos:

- representa a busca pelo que é essencial e absolutamente particular, já que as formas consagradas tornaram-se universais;

- valoriza o ato da criação, espontâneo, único, por captar apenas o instante psicológico (e conseqüentemente revelando o estado de alma de seu criador) 
descritivo - aquilo que pode ser visto ou sentido através da natureza objetiva ou imaginada.

- favorece a necessidade expressiva, agora prioridade, cabendo à forma apenas a função de acomodar conteúdos emocionais (o conceito de avaliação estético deixa de ser estético);

- a idéia fracionada, fragmentada, enquadra-se na noção de infinito (o instante não cabe nos limites da forma, por buscar o infinito).

Por outro lado, é na pequena forma que o compositor pratica a flexibilidade melódica, propícia ao extravasamento da sensibilidade, experimenta processos harmônicos inusitados, extrai deles novas cores, estimulado por um instrumento novo, agora repleto de recursos, o piano.

Além de favorecer a divulgação de diferentes danças, elementos originalmente espontâneos, é possível apreender, nas peças descritivas, a caracterização agora atribuída à natureza: uma natureza sujeito, personagem, presença forte, constante, não mais apenas cenário. Natureza confidente, que percebe e revela os estados de alma de quem a descreve.

A obra Macchiette, de Henrique Oswald, exemplifica de forma concreta o que é proposto nesta dissertação: reunindo os mais diversos tipos de peças freqüentes na época, retrata não só características comuns ao movimento romântico, como revela os processos composicionais e de estilo de seu criador. Tem-se, na realidade, a essência-essencial da criação oswaldiana em seu período florentino.

Portanto, o repertório romântico, constituído pela pequena forma pianística, propicia àquele que a estuda, não só o conhecimento dos diferentes processos utilizados no período, incluindo a diversidade proporcionada pelas características dos diferentes países, mas revela muito sobre o compositor, que faz dela uma 
síntese dos processos composicionais por ele utilizados e se deixa conhecer, ao transformá-la em veículo de expressão de seus sentimentos.

\section{Bibliografia}

\section{Livros}

ABBIATTI, Franco. Historia de La Musica. Ottocento (Siglo XIX). Mexico, Union Tipografia Editorial Hispano Americana, 1960.

BOSI, Alfredo. História Concisa da Literatura Brasileira. São Paulo, Cultrix, 1972.

CÂMARA, J. M. Bettencourt da. A Música para piano de Francisco de Lacerda. Lisboa, Instituto de Cultura e Língua Portuguesa, 1987.

CANDÉ, Roland de. Dictionnaire de Musique. Paris, Éditions du Seuil, 1961. . História Universal da Música. São Paulo, Martins Fontes, 2001. V. 2.

CARPEAUX, Otto Maria. O Livro de Ouro da História da Música. Rio de Janeiro, Ediouro, 2001.

CASELLA, Alfredo. El Piano. Buenos Aires, Ricordi Americana, 1946. 
CHANTAVOINE, Jean \& GAIDEFROY-DEMONBYNES, Jean. El Romanticismo en La Musica Europea. México, Union Tipografia Editorial Hispano Americana, 1958.

DALE, Kathleen. Nineteenth-Century Piano Music. London, Oxford University Press, 1954.

DORIAN, Frederick. Historia de la Musica Atraves de su ejecucion. Buenos Aires, Editorial Schapire, 1950.

DICIONÁRIO GROVE de MÚSICA: edição concisa. Rio de Janeiro, Jorge Zahar, 1994.

DICTIONNAIRE de la MUSIQUE. Paris, Larousse, 1990.

EINSTEIN, Alfred. Music in The Romantic Era. Londres, J. M. Dent \& Sons,1947.

GATT, Giuseppe. Constable. Barcelona, Ediciones Toray ,1968.

GRAÇA, Fernando Lopes. Reflexões sobre a música. Lisboa, Seara Nova, 1941.

GUINSBURG, J. O Romantismo. São Paulo, Perspectiva, 1978.

HANSLICK, Eduard. Do Belo Musical. Lisboa, Edições 70. 2002.

HARNONCOURT, Nikolaus. O Discurso dos Sons. Rio de Janeiro, Jorge Zahar, 1998.

HODEIR, André. Les Formes de la Musique. Paris, Presses Universitaires de France, 1051.

HOLST, Imogen. ABC da Música. São Paulo, Martins Fontes, 1987.

HORTA, Luiz Paulo. Villa-Lobos - uma introdução. Rio de Janeiro, Jorge Zahar, 1987. 
KIEFER, Bruno. Elementos da Linguagem Musical. Porto Alegre, Movimento, 1987.

LOCARD, Paul \& STRICKER, Rémy. Le Piano. Paris, Presses Universitaires de France, 1974.

LONGYEAR, Rey Morgan. Nineteenth-century romanticism in music. New Jersey, Prentice-Hall,1988.

MACHADO, Maria Célia. H.Villa-Lobos. Rio de Janeiro, UFRJ, 1987.

MANUEL, Roland. Plaisir de La Musique. Paris, Éditions du Seuil, 1974.

MARTINS, José Eduardo. Henrique Oswald Músico de uma saga romântica. São Paulo, EDUSP, 1995.

MASSIN, Jean \& Brigitte. História da Música Ocidental. Rio de Janeiro, Nova Fronteira, 1997.

OSBORNE, Harold. Estética e Teoria da Arte. São Paulo, Cultrix, 1968.

OSTROWER, Fayga. Cratividade e Processos de Criação. Rio de Janeiro, Vozes, 2004.

PAHLEN, Kurt. História Universal da Música. São Paulo, Melhoramentos, 1965.

ROSEN, Charles. A Geração Romântica. São Paulo, EDUSP, 2000.

SALAZAR, Adolfo. Forma y Expresion en la Musica. Mexico, El Colegio de Mexico, 1941.

. Síntesis de la história de la Música. Buenos Aires, Editorial Pleamar, 1945. 
. La Musica en la Sociedad Europea. Mexico, El Colégio de México, 1946. vol. 2,3 e 4 .

. Conceptos Fundamentales en la história de la musica. Madrid, Alianza

Editorial, 1988.

SARAIVA, António José \& LOPES, Oscar. História da Literatura Portuguesa. Porto, Porto Editora, s.d.

SCHOENBERG, Arnold. Fundamentos da Composição Musical. São Paulo, EDUSP, 1996.

STEHMAN, Jacques. História da Música Européia. São Paulo, Difusão Européia do Livro, 1964.

STOEKLIN, Paul de. Vida de Grieg. São Paulo, Livraria Cultura Brasileira, s.d.

STRAVINSKY, Igor. Poética Musical em 6 Lições. Rio de Janeiro, Zahar, 1996.

THE NEW GROVE DICTIONARY OF MUSIC AND MUSICIANS. London, Macmillan Publishers, 1980. vs. 15-16.

ZAMACOIS, Joaquin. Curso de formas musicales. Barcelona, Idea Books 2002.

\section{Artigos em Revistas e Capítulos em Livros}

BOULEZ, Pierre. "Encontro com Pierre Boulez". In: Revista Música. São Paulo, v.7, n.1/2, 1996, p.200-207.

OLIVEIRA, Franklin. "A Filosofia do Romantismo”. In: KELLY, Celso; GUDIN, Eugenio; CUNHA, Fausto e et al. Século XIX: O Romantismo. Rio de Janeiro, Museu Nacional de Belas Artes, 1979. 


\section{Tese Acadêmica}

MARTINS, José Eduardo. Henrique Oswald: Compositor Romântico. Tese de Doutorado. São Paulo, FFLCH-USP, 1988. V. 2.

\section{Anexo}

Partituras: Macchiette op. 2 de Henrique Oswald: 12 pequenas peças. 


\section{Henrique Oswald}

\section{Macchiette op. 2}

12 piccoli pezzi

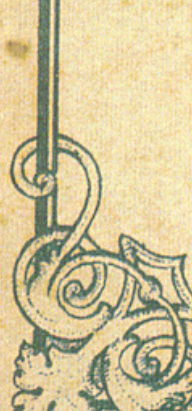

